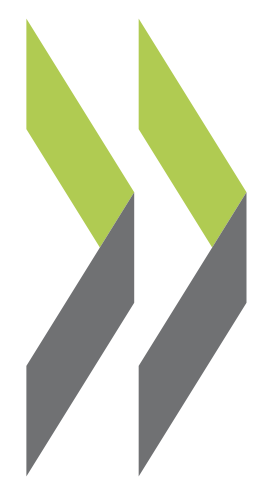

OECD Science, Technology and Industry Working Papers $2001 / 02$

Linking Entrepreneurship to Growth

\section{David B. Audretsch,}

\section{Roy Thurik}




\section{STI WORKING PAPERS 2001/2}

LINKING ENTREPRENEURSHIP TO GROWTH

David B. Audretsch and Roy Thurik 


\section{STI Working Paper Series}

The Working Paper series of the OECD Directorate for Science, Technology and Industry of the OECD is designed to make available to a wider readership selected studies prepared by staff in the Directorate or by outside consultants working on OECD projects. The papers included in the series are of a technical and analytical nature and deal with issues of data, methodology and empirical analysis in the areas of work of the DSTI. The Working Papers are generally available only in their original language - English or French - with a summary in the other.

Comment on the papers is invited, and should be sent to the Directorate for Science, Technology and Industry, OECD, 2 rue André Pascal, 75775 Paris Cedex 16, France.

The opinions expressed in these papers are the sole responsibility of the author(s) and do not necessarily reflect those of the OECD or of the governments of its Member countries.

\section{http://www.oecd.org/dsti/sti/prod/sti_wp.htm}


DSTI/DOC(2001)2

\title{
LINKING ENTREPRENEURSHIP TO GROWTH
}

\author{
David B. Audretsch, Indiana University and Centre for Economic Policy Research (CEPR), London, United \\ Kingdom, and Roy Thurik, Professor of Economics, Erasmus University-Rotterdam, and EIM Research \\ Consultancy, The Netherlands
}

This paper provides a link between the degree of entrepreneurial activity in a country and the growth performance. While a recent wave of empirical evidence suggests that the extent to which countries have shifted towards an increased role of entrepreneurship varies considerably across countries, virtually nothing is known about the consequences of lagging behind in this process. Do countries that have shifted towards a greater role for entrepreneurship enjoy greater growth? This question is crucial to policy makers, because if the opportunity cost, measured in terms of forgone growth, of a slow adjustment towards a greater role for entrepreneurship is relatively low, the consequences of not engaging in a rapid adjustment process are relatively trivial. However, if the opportunity cost is high, the consequences are more alarming. This paper offers two distinct approaches, based on two different measures of entrepreneurship - the relative share of economic activity accounted for by small firms, and the selfemployment rate. In addition, two different measures of performance of economic activity are also analysed economic growth and reduction of unemployment - to link changes in entrepreneurship to changes in economic performance. Different samples including OECD countries over different time periods reach consistent results increases in entrepreneurial activity tends to result in higher subsequent growth rates and a reduction of unemployment.

We are grateful to the suggestions of Thomas Andersson and the anonymous referees of the OECD on earlier drafts of this paper, as well as the contributions of our colleagues on various research projects and papers, Martin Carree and Andre van Stel. Some of the statistical results and analyses are taken from joint work with these co-authors. Any errors or omissions remain our responsibility.

\section{LIENS ENTRE ENTREPRENARIAT ET CROISSANCE}

David B. Audretsch, Indiana University et Centre for Economic Policy Research (CEPR), Londres, Royaume-Uni, et Roy Thurik, Professeur d'économie, Erasmus University-Rotterdam, et EIM Research Consultancy, Pays-Bas

Ce rapport se penche sur les liens qui unissent le degré d'entreprenariat d'un pays et le dynamisme de sa croissance. Si une récente déferlante de données empiriques semble indiquer que la mesure dans laquelle les pays développent l'entreprenariat varie sensiblement d'un pays à l'autre, on ne sait pratiquement rien des conséquences qui peuvent découler d'un retard en la matière. Les pays où l'entreprenariat a gagné en importance bénéficient-ils d'une croissance plus forte ? Cette question est vitale pour les décideurs car si le coût d'opportunité, mesuré en termes de moindre croissance, d'une adaptation lente au développement de l'entreprenariat est relativement faible, les conséquences d'une non participation à un processus d'adaptation rapide sont relativement insignifiantes. En revanche, si le coût d'opportunité est élevé, les conséquences sont plus inquiétantes. Ce rapport propose deux méthodes distinctes, fondées sur deux mesures différentes de l'entreprenariat - la part relative de l'activité économique imputable aux petites entreprises et la proportion de travailleurs indépendants. Il analyse en outre deux mesures différentes de la performance économique - la croissance économique et la réduction du chômage - en vue de dégager les liens qui existent entre l'évolution de l'entreprenariat et l'évolution de la performance économique. Différents exemples concernant des pays de l'OCDE pris à différentes périodes donnent des résultats concordants - le développement de l'entreprenariat tend à être suivi de taux de croissance plus élevés et d'une réduction du chômage.

Nous exprimons notre gratitude à Thomas Andersson et aux agents anonymes de l'OCDE qui nous ont fait part de leurs suggestions concernant les versions antérieures du présent rapport, ainsi qu'à nos collègues Martin Carree et Andre van Stel pour les contributions qu'ils ont apportées à divers projets et travaux de recherche. Certains des résultats et analyses statistiques sont extraits de travaux effectués conjointement avec ces coauteurs. Toute erreur ou omission relèverait de notre seule responsabilité. 
DSTI/DOC(2001)2

\section{LINKING ENTREPRENEURSHIP TO GROWTH}

\section{Introduction}

Explanations for economic growth have generally been restricted to the realm of macroeconomics (Romer, 1990; Krugman, 1991). However, a different scholarly tradition linking growth to industrial organisation dates back at least to Schumpeter (1934). According to this tradition, performance, measured in terms of economic growth, is shaped by the degree to which the industry structure most efficiently utilises scarce resources. This leads Dosi (1988, p.1157), in his systematic review of the literature in the Journal of Economic Literature, to conclude that: "Each production activity is characterised by a particular distribution of firms."

When the determinants of the underlying industrial structure are stable, the industry structure itself would not be expected to change. However, as Chandler (1990), Scherer and Ross (1990) and Dosi (1988) emphasise, a change in the underlying determinants would be expected to result in a change in the industry structure most conducive to growth. Certainly, Chandler (1990) and Scherer and Ross (1990) identified a shift in industry structure towards increased centralisation and concentration throughout the first two-thirds of the previous century as a result of changes in the underlying technology along with other factors.

More recently, a series of studies has identified a change in the determinants underlying the industry structure that has reversed this trend (Audretsch, Baumol and Burke, 2001). The most salient point of this change is that technology, globalisation, deregulation, labour supply, variety in demand, and the resulting higher levels of uncertainty have rendered a shift in the industry structure away from greater concentration and centralisation towards less concentration and decentralisation. A series of empirical studies (Loveman and Sengenberger, 1991; Acs and Audretsch, 1993) have uncovered two systematic findings regarding the response of industry structure to changes in the underlying determinants. The first is that the industry structure is generally shifting towards an increased role for small enterprises. The second is that the extent and timing of this shift is anything but identical across countries. Rather, the shift in industry structures towards a greater role for SMEs has been heterogeneous and apparently shaped by country-specific factors. Apparently, institutions and policies in certain countries have facilitated a greater and more rapid response to globalisation and technological change, along with the other underlying factors, by shifting to a less centralised and more dispersed industry structure than has been the case in other countries. An implication of this high variance in the shift towards SMEs is that some countries are likely to experience more growth than are others.

While the evidence suggests that the degree to which countries have shifted towards an increased role of SMEs varies considerably across countries, virtually nothing is known about the consequences of lagging behind in this process. Do countries that have shifted towards a greater role for entrepreneurship enjoy greater growth? This question is crucial to policy makers, because if the opportunity cost, measured in terms of forgone growth, of a slow adjustment towards a greater role for entrepreneurship is relatively low, the consequences of not engaging in a rapid adjustment process are relatively trivial. However, if the opportunity cost is high, the consequences are more alarming. The purpose of this paper is to identify the impact of entrepreneurship on growth at the country level. 
In the second section of the paper we explain what is known about the links between entrepreneurship and economic growth and where the gaps and research challenges lie. In particular, although recent literature has emerged identifying the microfoundations linking entrepreneurship to growth for the unit of observations of the enterprise, as well as for the geographic unit of observation of the region, very little is known about the impact of entrepreneurship on economic growth at the macroeconomic level.

An important contribution of the new economic growth theory (Romer, 1987 and 1990) has been to identify the central role that knowledge, and knowledge spillovers in particular, play in generating growth. A central argument of this paper is that globalisation has shifted the comparative advantage of high-cost OECD countries away from the traditional factors of production and towards the factor of knowledge and ideas. Because of the inherent qualities of knowledge - uncertainty, asymmetries and high transactions cost - entrepreneurship becomes more important in a knowledge-based economy. Entrepreneurship provides one of the key mechanisms by which new economic knowledge spills over from the source to those commercialising it. The third section of the paper documents the extent to which globalisation is triggering a shift in the comparative advantage towards knowledge.

The fourth section of this paper provides a conceptual framework for linking entrepreneurship to growth. This framework is based on the competitive advantage of entrepreneurial firms in a globalise economy where knowledge plays an increased role. While the new economic growth theory, posited by Romer (1990), Krugman (1991) and others identifies the key role that knowledge spillovers play in generating increasing returns and ultimately contributing to higher growth, they are less precise about the actual mechanisms transmitting such knowledge spillovers. This framework suggests that entrepreneurial firms serve as an important vehicle in the transmission of knowledge spillovers. Thus, by serving as a vehicle for knowledge transmission and spillover, entrepreneurship plays a key role in the link between knowledge and growth.

If entrepreneurship is difficult to define, it is even more difficult to measure. The fifth section discusses issues involved in trying to operational the concept of entrepreneurship. We emphasise that measuring entrepreneurship, particularly in a cross-national context is difficult and fraught with limitations. We then rely on one broad measure to document the shift in the relative importance of entrepreneurship over time across a broad spectrum of OECD countries.

Because of measurement limitations, two separate empirical analyses are undertaken in the sixth section to identify the impact of changes of entrepreneurship on growth. Each one uses a different measure of entrepreneurship, sample of countries and specification. This provides some sense of robustness across different measures of entrepreneurship, data sets, time periods and specifications. The first analysis uses a data base, which measures entrepreneurship in terms of the relative share of economic activity accounted for by small firms. It links changes in entrepreneurship to growth rates for a panel of 18 OECD countries spanning five years to test the hypothesis that higher rates of entrepreneurship lead to greater subsequent growth rates. The second analysis uses a measure of self-employment as an index of entrepreneurship and links changes in entrepreneurship to unemployment at the country level between 1974 and 1998.

The seventh section of the paper considers the implications for public policy. The first part of the section argues that, based on the findings of this paper policies that generate and encourage entrepreneurship are key instruments for stimulating economic growth. The second part examines the role that public policy has played. In particular, it is suggested that a shift in public policy is taking place away from policies that constrain the freedom of firms to contract and towards policies enabling the start-up and viability of knowledge-based entrepreneurial firms. Finally, in the last section conclusions are provided. In particular, we find that both types of analyses suggest that, using a broad spectrum of OECD countries and time periods, shifting towards a greater role of entrepreneurial activity has resulted in greater rates of growth as well as lower rates of unemployment. 


\section{The research gap}

There is a considerable gap of research linking entrepreneurship to economic growth. The reasons for this void in the state of knowledge about the impact of entrepreneurship on economic growth may be attributable to a paucity of theoretical frameworks linking entrepreneurship to growth as well as severe constraints in measuring entrepreneurship, let alone entrepreneurship within a cross-national context.

The last two decades have seen an explosion in studies analysing the determinants of entrepreneurship. While some of these studies are theoretical (Holmes and Schmitz, 1990), others are empirical (Evans and Leighton, 1990 and Evans and Jovanovic, 1989; Reynolds, 1997). What they have in common is to pose the questions: "Why do people start firms and what determines who becomes an entrepreneur?"

The consequences of entrepreneurship, in terms of economic performance, have also generated substantial literature. However, this literature has been restricted to two units of observations - at the level of the establishment or enterprise, and for regions. Noticeably absent are studies linking the impact of entrepreneurship on performance for the unit of observation of the country. In fact, a large literature has emerged analysing the impact of entrepreneurship on economic performance at the level of the firm or establishment. These studies typically measure economic performance in terms of enterprise growth and survival (Audretsch, 1995; Caves, 1998; Sutton, 1997). The compelling stylised facts that have emerged from this literature is that entrepreneurial activity, measured in terms of firm size and age, is positively related to growth. The growth of new firms and small firms is systematically greater than for large and established incumbents. These findings hold across OECD countries and across time periods.

The link between entrepreneurship and performance has also been extended beyond the unit of observation of the firm to include a geographic region. Much has been written about linking measures of entrepreneurial activity for regions to the economic performance of those regions (Reynolds, Storey and Westhead, 1994; Reynolds, Miller and Maki, 1995; Audretsch and Fritsch, 2001).While Reynolds, Miller and Maki (1995) find that the degree of entrepreneurship has a positive impact on regional economic growth in the United States, Audretsch and Fritsch find that for Germany the relationship shifted from negative in the 1980s to positive in the 1990s.

However, when it comes to linking entrepreneurship to growth at the national level, there is a void. The purpose of this paper is to fill this gap in research by making the links between entrepreneurial activity and macroeconomic growth explicit. To accomplish this goal we must overcome both a paucity of theory as well as severe measurement challenges. Our research strategy is to exploit what has been learned from the literature identifying the microeconomic foundations of growth and relating that literature to the endogenous growth literature, which emphasises the role of knowledge externalities in the growth process (Romer, 1987).

\section{Globalisation and the shift to a knowledge economy}

Perhaps one of the least understood phenomena accompanying the increased globalisation at the close of the $21^{\text {st }}$ century has been a shift in the comparative advantage of high-wage countries towards knowledge-based economic activity. An important implication of this shift in this comparative advantage is that much of the production and commercialisation of new economic knowledge is less associated with footloose multinational corporations and more associated with high-tech clusters populated by innovative entrepreneurial firms, such as Silicon Valley, Research Triangle and Route 122. Only a few years ago conventional wisdom predicted that globalisation would render the demise of small- and medium-sized enterprises. Yet the obsession of policy-makers around the globe to "create the next Silicon Valley" reveals the increased importance of entrepreneurship and small technology-based firms. The purpose of this paper 
is to provide a link between this change in the industry structure towards entrepreneurship and SMEs, on the one hand, and economic growth on the other.

The driving force underlying the emerging globalisation has been technology. While there are many different aspects to the technological revolution, the advent of the microprocessor combined with its application in telecommunications has altered the economic meanings of national borders and distance.

Observing the speed at virtually no cost with which information can be transmitted across geographic space via the internet, fax machines and electronic communication superhighways, The Economist recently proclaimed on its title page the, "The Death of Distance." The new communications technologies have triggered a virtual spatial revolution in terms of the geography of production. According to The Economist, "The death of distance as a determinant of the cost of communications will probably be the single most important economic force shaping society in the first half of the next century." What the telecommunications revolution has done is to reduce the cost of transmitting information across geographic space to virtually zero. At the same time, the microprocessor revolution has made it feasible for nearly everyone to participate in global communications.

The number of Internet hosts world-wide has exploded just in the decade of the 1990s. ${ }^{2}$ There were almost no hosts at the start of the decade and approaching ten million hosts by the end of the decade. This explosion in the Internet corresponds to a vast increase in investment in information and communication technologies. Information and communication technologies are accounting for a greater share of investment between the 1980s and 1990s in major OECD countries. A recent survey of use in higher education in the United States revealed an increasing reliance on information technologies by universities (OECD, 1998). In 1995 less than two-thirds of the American campus systems were connected to an IT network; within two years, $81 \%$ were connected.

The advent of global telecommunications has made the interaction between individuals possible at a trivial cost. For example, international collaboration in publications in physics increased for American scientists from $8.8 \%$ in 1981 to $17.1 \%$ in 1991. International collaboration during this period doubled in physics, biology and chemistry. Inferences about the degree of and increase in globalisation based on international trade statistics miss an important point - it is the quality and not just the quantity of international transactions that have changed. Interaction among individuals adds a very different quality to the more traditional measures of trade, foreign direct investment and capital flows - and also has very different implications for the development of economic activities. This additional quality contributed by the transnational interactions of individuals, and not just arms-lengths transactions by corporations exposes people to ideas and experiences that were previously inaccessible.

Globalisation would not have occurred to the degree that it has if the fundamental changes were restricted to the advent of the microprocessor and telecommunications. It took a political revolution in significant parts of the world to reap the benefits from these technological changes. The political counterpart of the technological revolution was the increase in democracy and concomitant stability in areas of the world that had previously been inaccessible. The Cold War combined with internal political instability rendered potential investments in Eastern Europe and much of the developing world as risky and impractical. During the post-war era most trade and economic investment was generally confined to Europe and North America, and later a few of the Asian countries, principally Japan and the Asian Tigers. Trade with countries behind the iron curtain was restricted and in some cases prohibited. Even trade with Japan and other Asian countries was highly regulated and restricted. Similarly, investments in politically unstable countries in South America and the Mid-East resulted in episodes of national take-overs and confiscation where the foreign investors lost their investments. Such political instability rendered foreign direct investment outside of Europe and North America to be particularly risky and of limited value.

The fall of the Berlin Wall and subsequent downfall of communism in Eastern Europe and the former Soviet Union was a catalyst for stability and accessibility to parts of the world that had previously been 


\section{DSTI/DOC(2001)2}

inaccessible for decades. Within just a few years it has become possible not just to trade with but also to invest in countries such as Hungary, the Czech Republic, Poland, Slovenia, as well as China, Vietnam and Indonesia. For example, India became accessible as a trading and investment partner after opening its economy in the early 1990s. Trade and investment with the developed countries quickly blossomed. Trade and investment with the United States tripled between 1996 and 1997, reflecting the rapid change in two dimensions. First, India was confronted with sudden changes in trade and investment, not to mention a paradigmatic shift in ways of doing business. Second, to the foreign partner, in this case the United States, taking advantage of opportunities in India also meant downward pressure on wages and even plant closings in the home country.

With the opening of some of these areas and participating in the world economy for the first time in decades, the post-war equilibrium came to a sudden end. This created the opportunities associated with gaping disequilibria. Consider the large differentials in labour costs. As long as the Berlin Wall stood, and countries such as China and Vietnam remained closed, large discrepancies in wage rates could be maintained without eliciting responses in trade and foreign direct investment. The low wage rates in China or parts of the former USSR neither invited foreign companies to build plants nor resulted in large-scale trade with the West based on access to low production costs. Investment by foreign companies was either prohibited by local governments or considered to be too risky by the companies. Similarly trade and other restrictions limited the capabilities of firms in those countries from being able to produce and trade with western nations.

Thus, the gaping wage differentials existed while the Wall stood and much of the communist world was cut off from the West were suddenly exposed in the early 1990s. There were not only unprecedented labour cost differentials but also massive and willing populations craving to join the high levels of consumption that had become the norm in Western Europe and North America. ${ }^{3}$ For example, in the early part of the 1990s, the daily earnings of labour were estimated to be USD 92.24 in the United States and USD 78.34 in the European Union. This was a sharp contrast shortly after the Berlin Wall fell and wages were only USD 6.14 in Poland and USD 6.45 in the Czech Republic. In Asia, the wage gap was even greater, where the daily earnings were USD 1.53 in China, USD 2.46 in India and USD 1.25 in Sri Lanka. The potential labour force in countries like China, with 464 million workers, and India with 341 million workers dwarfs the workforce in North America and Europe.

Of course, the productivity of labour is vastly greater in the West, which compensates to a significant degree for such large wage differentials. Still, given the magnitude of these numbers both trade and investment have responded to the opportunities made possible by the events of 1989 .

While the most salient feature of globalisation involves interaction and interfaces among individuals across national boundaries, the more traditional measures of transnational activity reflect an upward trend of global activities. These traditional measures include trade (exports and imports), foreign direct investment (inward and outward), international capital flows, and inter-country labour mobility. The overall trend for all of these measures has been strongly positive. The trade of goods nearly tripled between 1985 and 1996. The trade of services increased by more than three times over this time period. The increases in investment income, direct investment and portfolio investment were even greater. But the increase in all of these measures within just over a decade reflects the increasing degree of globalisation.

The degree of world trade, measured by exports and imports has increased over time. World exports increased from USD 1.3 trillion in 1970 to nearly USD 5 trillion in 1999, in constant dollars. While some of this increase in the world export rate is attributable to an increased participation in international trade by countries which had previously been excluded, export rates in the leading industrialised countries have also increased over the past three decades. ${ }^{4}$ For example, US exports and imports have increased from $11 \%$ of GDP in 1970 to more than $25 \%$ by 1999 . 
The world volume of trade has increased by nearly $400 \%$ between 1970 and 1997 . Over this same period global production has only doubled. In the most developed countries the increase in trade has been even greater. For example, exports as a share of gross domestic product for 49 developed countries has risen from around $18 \%$ in 1982 to around $25 \%$ by 1999. Similarly, real exports have increased in the United States from USD 86.8 billion in 1960, to USD 818.0 billion in 1996. At the same time, real imports have risen from USD 108.1 billion to USD 883.0 billion.

The increase in world trade is also not attributable to the influence of just a few industries or sectors, but is rather systematic across most parts of the economy. The exposure to foreign competition in manufacturing increased by about one-sixth in the OECD countries. The exposure to foreign competition increased in every single OECD country, with the exception of Japan. In addition, it increased in most of the manufacturing industries.

A different manifestation of globalisation involves foreign direct investment, which has increased by $700 \%$ between 1970 and 1997 for the entire world. The increase in global FDI has also not been solely the result of a greater participation by countries previously excluded from the world economy. FDI as a percentage of GDP increased in the 1970s, 1980s and 1990s for the major economies of the United States and the engine of the European economy, Germany. In the United States, annual FDI represented slightly more than $1 \%$ of GDP during the 1970s. In the 1980s, this had risen to around $1.2 \%$. By the 1990s annual FDI was more than $1.5 \%$ of GDP. For the United States outward foreign direct investment increased from USD 1637.1 billion in 1987 to USD 2931.9 billion in 1995. Inward foreign direct investment into the United States increased from USD 1385.9 billion to USD 3745.9 billion over this same time period.

Trans-national capital flows have also increased in the past two decades. The value of bonds and equities involved in cross-border transactions has exploded over the past two decades for the six of the largest economies. In addition, the amount of foreign exchange traded has also increased. The cross-border transactions in bonds and equities as a percentage of GDP rose in the United States from 9.0\% in 1980 to $135.5 \%$ by 1995 . In Italy the increase was from $1.1 \%$ to $250.9 \%$, and in Germany from $7.5 \%$ to $168.3 \%$.

Confronted with lower cost competition in foreign locations, producers in the high-cost countries have had three options apart from doing nothing and losing global market share: $i$ ) reduce wages and other production costs sufficiently to compete with the low-cost foreign producers; ii) substitute equipment and technology for labour to increase productivity; and iii) shift production out of the high-cost location and into the low-cost location.

Many of the European and American firms that have successfully restructured resorted to the last two alternatives. Substituting capital and technology for labour, along with shifting production to lower-cost locations has resulted in waves of Corporate Downsizing throughout Europe and North America. At the same time, it has generally preserved the viability of many of the large corporations. As record levels of both European and American stock indexes indicate, the companies have not generally suffered. For example, between 1979 and 1995 more than 43 million jobs were lost in the United States as a result of corporate downsizing (Audretsch and Thurik, 1999). This includes 24.8 million blue-collar jobs and 18.7 million white-collar jobs. Similarly, the 500 largest US manufacturing corporations cut 4.7 million jobs between 1980 and 1993, or one quarter of their workforce. ${ }^{5}$ Perhaps most disconcerting, the rate of corporate downsizing has apparently increased over time in the United States, even as the unemployment rate has fallen. During most of the 1980s, about one in 25 workers lost a job. In the 1990s this has risen to one in 20 workers.

The experience has not been different in Europe. Pressed to maintain competitiveness in traditional industries, where economic activity can be easily transferred across geographic space to access lower production costs, the largest and most prominent German companies have deployed two strategic responses. The first is to offset greater wage differentials between Germany and low-cost locations by 


\section{DSTI/DOC(2001)2}

increasing productivity through the substitution of technology and capital for labour. The second is to locate new plants and establishments outside of Germany. What both strategic responses have in common is that the German flagship companies have been downsizing the amount of employment in the domestic economy. For example, Siemens increased the amount of employment outside Germany by $50 \%$, from 108000 in 1984-85 to 162000 in 1994-95. Over the same time period it decreased the amount of employment in Germany by $12 \%$, from 240000 to 211000 .Volkswagen increased the amount of employment in foreign countries by 24\%, from 78000 in 1984 to 97000 in 1994 . Over the same time period, it decreased employment in Germany by $10 \%$, from 156000 to 141000 . Similarly, Hoechst increased the number of jobs outside of Germany by 9\%, from 78925 in 1984 to 92333 in 1994. The number of Hoechst employees in Germany fell over that same period by 26\%, from 99015 to 73 338. And BASF increased employment in foreign countries by 34\%, from 29966 in 1984 to 40297 in 1994. Domestic employment by BASF fell by 17\% over that same time period, from 85850 to 65969 .

These examples are not isolated but rather typical of the wave of downsizing in Germany in the 1990s that has resulted in levels of unemployment -4 million - not seen since the Second World War. As Table 1 shows, between 1991 and 1995 manufacturing employment in German plants decreased by 1307000 while it increased in foreign subsidiaries by 189000 (BMWi, 2000). In the chemical sector, the decrease of domestic employment was 80 000, while 1400 jobs were added by German chemical companies in plants located outside of Germany. In electrical engineering employment in German plants decreased by 198000. In automobiles employment in Germany decreased by 161000 , while 30000 jobs were added outside of Germany.

Table 1. Change in employment figures in western Germany and at foreign subsidiaries, 1991-95

In thousands

\begin{tabular}{|c|c|c|c|c|c|c|c|}
\hline $\begin{array}{l}\text { Employment } \\
\text { trend }\end{array}$ & Manufacturing & Chemicals & $\begin{array}{l}\text { Electrical } \\
\text { Engineering }\end{array}$ & Automotive & $\begin{array}{l}\text { Mechanical } \\
\text { Engineering }\end{array}$ & Textiles & $\begin{array}{l}\text { Banking } \\
\text { and } \\
\text { insurance }\end{array}$ \\
\hline Foreign & +189 & +14 & -17 & +30 & +16 & -6 & +21 \\
\hline Domestic (west) & -1.307 & -80 & -198 & -161 & -217 & -68 & +28 \\
\hline
\end{tabular}

Source: BMWi (2000)

Between 1991 and 1995 employment in manufacturing in establishments located in (west) Germany decreased by 1307000 . At the same time, employment in German subsidiaries located outside of Germany increased by 189 000. Employment decreased in German establishments located in Germany while increased in establishments in foreign countries in all of the major manufacturing sectors, including chemicals, electrical engineering, automobiles, and mechanical engineering.

Much of the policy debate responding to the twin forces of the telecommunications revolution and increased globalisation has revolved around a trade-off between maintaining higher wages but suffering greater unemployment versus higher levels of employment but at the cost of lower wage rates. There is, however, an alternative. It does not require sacrificing wages to create new jobs, nor does it require fewer jobs to maintain wage levels and the social safety net. This alternative involves shifting economic activity out of the traditional industries where the high-cost countries of Europe and North America have lost the comparative advantage and into those industries where the comparative advantage is compatible with both high wages and high levels of employment - knowledge based economic activity.

Globalisation has rendered the comparative advantage in traditional moderate technology industries incompatible with high wage levels. At the same time, the emerging comparative advantage that is compatible with high wage levels is based on innovative activity. For example, employment has increased 
by $15 \%$ in Silicon Valley between 1992 and 1996, even though the mean income is $50 \%$ greater than in the rest of the country.

There are many studies documenting the shift in the comparative advantage of the high-wage countries towards an increased importance knowledge-based economic activity. For example, Kortum and Lerner (1997, p. 1) point to "the unprecedented recent jump in patenting in the United States", as evidenced by the rise in applications for US patents by American inventors since 1985, which exceeds the increase in any other decade in this century. Throughout this century, patent applications fluctuated within a band of between 40000-80000 per year. By contrast, in 1995 there were over 120000 patent applications. Similarly, Berman, Bound and Machin (1997) have shown that the demand for less skilled workers has decreased dramatically throughout the OECD, while at the same time the demand for skilled workers has exploded. That globalisation is one of the defining changes at the turn of the century is clear from a reading of the popular press. Like all grand concepts, a definition for globalisation is elusive and elicits criticism. That domestic economies are globalising is a cliché makes it no less true. In fact, the shift in economic activity from a local or national sphere to an international or global orientation ranks among the most vehement changes shaping the current economic landscape.

\section{Entrepreneurship and growth}

\section{Entrepreneurship and innovation}

The increased importance of knowledge as a source of competitiveness for OECD countries suggests that the organisation of industries most conducive to innovative activity will be linked to higher growth rates. The starting point for most theories of innovation is the firm. In such theories the firms are exogenous and their performance in generating technological change is endogenous. For example, in the most prevalent model found in the literature of technological change, the model of the knowledge production function, formalised by Griliches (1979), firms exist exogenously and then engage in the pursuit of new economic knowledge as an input into the process of generating innovative activity.

The most decisive input in the knowledge production function is new economic knowledge. And as Cohen and Klepper (1991 and 1992) conclude, the greatest source generating new economic knowledge is generally considered to be R\&D. Certainly a large body of empirical work has found a strong and positive relationship between knowledge inputs, such as $R \& D$, on the one hand, and innovative outputs on the other hand.

The knowledge production function has been found to hold most strongly at broader levels of aggregation. The most innovative countries are those with the greatest investments to R\&D. Little innovative output is associated with less developed countries, which are characterised by a paucity of production of new economic knowledge. Similarly, the most innovative industries also tend to be characterised by considerable investments in R\&D and new economic knowledge. Not only are industries such as computers, pharmaceuticals and instruments high in R\&D inputs that generate new economic knowledge, but also in terms of innovative outputs (Audretsch, 1995). By contrast, industries with little $\mathrm{R} \& \mathrm{D}$, such as wood products, textiles and paper, also tend to produce only a negligible amount of innovative output. Thus, the knowledge production model linking knowledge generating inputs to outputs certainly holds at the more aggregated levels of economic activity.

Where the relationship becomes less compelling is at the disaggregated microeconomic level of the enterprise, establishment, or even line of business. For example, while Acs and Audretsch (1990) found that the simple correlation between $R \& D$ inputs and innovative output was 0.84 for four-digit standard industrial classification (SIC) manufacturing industries in the United States, it was only about half, 0.40 among the largest US corporations. 


\section{DSTI/DOC(2001)2}

The model of the knowledge production function becomes even less compelling in view of the recent wave of studies revealing that small enterprises serve as the engine of innovative activity in certain industries. These results are startling, because as Scherer (1991) observes, the bulk of industrial R\&D is undertaken in the largest corporations; small enterprises account only for a minor share of R\&D inputs. Thus the knowledge production function seemingly implies that, as the Schumpeterian Hypothesis predicts, innovative activity favours those organisations with access to knowledge-producing inputs - the large incumbent organisation. The more recent evidence identifying the strong innovative activity raises the question: "Where do new and small firms get the innovation producing inputs, that is, the knowledge?"

One answer, proposed by Audretsch (1995), is that, although the model of the knowledge production function may still be valid, the implicitly assumed unit of observation - at the level of the firm - may be less valid. The reason why the knowledge production function holds more closely for more aggregated degrees of observation may be that investment in $R \& D$ and other sources of new knowledge spills over for economic exploitation by third-party firms.

A large literature has emerged focusing on what has become known as the appropriability problem. The underlying issue revolves around how firms which invest in the creation of new economic knowledge can best appropriate the economic returns from that knowledge (Arrow, 1962). Audretsch (1995) proposes shifting the unit of observation away from exogenously assumed firms to individuals - agents with endowments of new economic knowledge. But when the lens is shifted away from focusing upon the firm as the relevant unit of observation to individuals, the relevant question becomes: How can economic agents with a given endowment of new knowledge best appropriate the returns from that knowledge?

The appropriability problem confronting the individual may converge with that confronting the firm. Economic agents can and do work for firms, and even if they do not, they can potentially be employed by an incumbent firm. In fact, in a model of perfect information with no agency costs, any positive economies of scale or scope will ensure that the appropriability problems of the firm and individual converge. If an agent has an idea for doing something different than is currently being practised by the incumbent enterprises - both in terms of a new product or process and in terms of organisation - the idea, which can be termed as an innovation, will be presented to the incumbent enterprise. Because of the assumption of perfect knowledge, both the firm and the agent would agree upon the expected value of the innovation. But to the degree that any economies of scale or scope exist, the expected value of implementing the innovation within the incumbent enterprise will exceed that of taking the innovation outside of the incumbent firm to start a new enterprise. Thus, the incumbent firm and the inventor of the idea would be expected to reach a bargain splitting the value added to the firm contributed by the innovation. The payment to the inventor - either in terms of a higher wage or some other means of remuneration - would be bounded between the expected value of the innovation if it implemented by the incumbent enterprise on the upper end, and by the return that the agent could expect to earn if he used it to launch a new enterprise on the lower end. Thus, each economic agent would choose how to best appropriate the value of his endowment of economic knowledge by comparing the wage he would earn if he remains employed by an incumbent enterprise, $w$, to the expected net present discounted value of the profits accruing from starting a new firm, $\pi$. If these two values are relatively close, the probability that he would choose to appropriate the value of his knowledge through an external mechanism such as starting a new firm, $\operatorname{Pr}(\mathrm{e})$, would be relatively low. On the other hand, as the gap between $w$ and $\pi$ becomes larger, the likelihood of an agent choosing to appropriate the value of his knowledge externally through starting a new enterprise becomes greater, or:

$$
\operatorname{Pr}(e)=f(\pi-w)(1)
$$

This model refocuses the unit of observation away from firms deciding whether to increase their output from a level of zero to some positive amount in a new industry, to individual agents in possession of new knowledge that, due to uncertainty, may or may not have some positive economic value. It is the 
uncertainty inherent in new economic knowledge, combined with asymmetries between the agent possessing that knowledge and the decision making vertical hierarchy of the incumbent organisation with respect to its expected value that potentially leads to a gap between the valuation of that knowledge.

How the economic agent chooses to appropriate the value of his knowledge, that is either within an incumbent firm or by starting or joining a new enterprise will be shaped by the knowledge conditions underlying the industry. Under what Nelson and Winter (1982) term as the routinised technological regime the agent will tend to appropriate the value of his new ideas within the boundaries of incumbent firms. Thus, the propensity for new firms to be started should be relatively low in industries characterised by the routinised technological regime.

By contrast, under the entrepreneurial regime the agent will tend to appropriate the value of his new ideas outside of the boundaries of incumbent firms by starting a new enterprise. Thus, the propensity for new firms to enter should be relatively high in industries characterised by the entrepreneurial regime.

Audretsch (1995) suggests that divergences in the expected value regarding new knowledge will, under certain conditions, lead an agent to exercise what Albert O. Hirschman (1970) has termed as exit rather than voice, and depart from an incumbent enterprise to launch a new firm. But who is right, the departing agents or those agents remaining in the organisational decision making hierarchy who, by assigning the new idea a relatively low value, have effectively driven the agent with the potential innovation away? Ex post the answer may not be too difficult. But given the uncertainty inherent in new knowledge, the answer is anything but trivial $a$ priori.

Thus, when a new firm is launched, its prospects are shrouded in uncertainty. If the new firm is built around a new idea, i.e. potential innovation, it is uncertain whether there is sufficient demand for the new idea or if some competitor will have the same or even a superior idea. Even if the new firm is formed to be an exact replica of a successful incumbent enterprise, it is uncertain whether sufficient demand for a new clone, or even for the existing incumbent, will prevail in the future. Tastes can change, and new ideas emerging from other firms will certainty influence those tastes.

Finally, an additional layer of uncertainty pervades a new enterprise. It is not known how competent the new firm really is, in terms of management, organisation, and workforce. At least incumbent enterprises know something about their underlying competencies from past experience. Which is to say that a new enterprise is burdened with uncertainty as to whether it can produce and market the intended product as well as sell it. In both cases the degree of uncertainty will typically exceed that confronting incumbent enterprises.

This initial condition of not just uncertainty, but a greater degree of uncertainty vis-à-vis incumbent enterprises in the industry is captured in the theory of firm selection and industry evolution proposed by Boyan Jovanovic (1982). Jovanovic presents a model in which the new firms, which he terms entrepreneurs, face costs that are not only random but also differ across firms. A central feature of the model is that a new firm does not know what its cost function is, that is its relative efficiency, but rather discovers this through the process of learning from its actual post-entry performance. In particular, Jovanovic (1982) assumes that entrepreneurs are unsure about their ability to manage a new-firm start-up and therefore their prospects for success. Although entrepreneurs may launch a new firm based on a vague sense of expected post-entry performance, they only discover their true ability - in terms of managerial competence and of having based the firm on an idea that is viable on the market - once their business is established. Those entrepreneurs who discover that their ability exceeds their expectations expand the scale of their business, whereas those discovering that their post-entry performance is less than commensurate with their expectations will contact the scale of output and possibly exit from the industry. Thus, Jovanovic's model is a theory of noisy selection, where efficient firms grow and survive and inefficient firms decline and fail. 


\section{DSTI/DOC(2001)2}

The theory of firm selection is particularly appealing in view of the rather startling size of most new firms. For example, the mean size of more than 11000 new-firm start-ups in the manufacturing sector in the United States was found to be fewer than eight workers per firm (Audretsch, 1995). While the minimum efficient scale (MES) varies substantially across industries, and even to some degree across various product classes within any given industry, the observed size of most new firms is sufficiently small to ensure that the bulk of new firms will be operating at a suboptimal scale of output. Why would an entrepreneur start a new firm that would immediately be confronted by scale disadvantages?

An implication of the theory of firm selection is that new firms may begin at a small, even suboptimal, scale of output, and then if merited by subsequent performance expand. Those new firms that are successful will grow, whereas those that are not successful will remain small and may ultimately be forced to exit from the industry if they are operating at a suboptimal scale of output.

An important implication of the dynamic process of firm selection and industry evolution is that new firms are more likely to be operating at a suboptimal scale of output if the underlying technological conditions are such that there is a greater chance of making an innovation, that is under the entrepreneurial regime. If new firms successfully learn and adapt, or are just plain lucky, they grow into viably sized enterprises. If not, they stagnate and may ultimately exit from the industry. This suggests, that entry and the start-up of new firms may not be greatly deterred in the presence of scale economies. As long as entrepreneurs perceive that there is some prospect for growth and ultimately survival, such entry will occur. Thus, in industries where the MES is high, it follows from the observed general small size of newfirm start-ups that the growth rate of the surviving firms would presumably be relatively high.

At the same time, those new firms not able to grow and attain the MES level of output would presumably be forced to exit from the industry, resulting in a relatively low likelihood of survival. In industries characterised by a low MES, neither the need for growth, nor the consequences of its absence are as severe, so that relatively lower growth rates but higher survival rates would be expected. Similarly, in industries where the probability of innovating is greater, more entrepreneurs may actually take a chance that they will succeed by growing into a viably sized enterprise. In such industries, one would expect that the growth of successful enterprises would be greater, but that the likelihood of survival would be correspondingly lower.

\section{Entrepreneurship as a mechanism for knowledge spillovers}

The recent wave of studies revealing that small enterprises serve as the engine of innovative activity in certain industries (Audretsch, 1995; Acs and Audretsch, 1988 and 1990) is particularly startling, because the bulk of industrial R\&D is undertaken in the largest corporations; small enterprises account for only a minor share of R\&D inputs (Scherer, 1992; Cohen and Klepper, 1992). Thus, the model of the knowledge production function seemingly implies that innovative activity favours those organisations with access to knowledge-producing inputs - large organisations. The more recent evidence identifying the role of small firms as a source of innovative activity raises the question: Where do entrepreneurial small firms get the innovation-producing inputs, that is the knowledge?

One suggested answer is that although the model of the knowledge production function may certainly be valid, the implicitly assumed unit of observation which links the knowledge inputs with the innovative outputs - at the level of the establishment or firm - may be less valid. Instead, recent literature suggests that knowledge spills over from the firm or research institute producing it to a different firm commercialising that knowledge (Griliches, 1992). This view is supported by theoretical models which have focused on the role that spillovers of knowledge across firms play in generating increasing returns and ultimately economic growth (Romer, 1986, 1990 and 1994; Krugman, 1991). 
An important theoretical development is that geography may provide a relevant unit of observation within which knowledge spillovers occur. The theory of localisation suggests that because geographic proximity is needed to transmit knowledge and especially tacit knowledge, knowledge spillovers tend to be localised within a geographic region. The importance of geographic proximity for knowledge spillovers has been supported in a wave of recent empirical studies by Jaffe (1989), Jaffe, Trajtenberg and Henderson (1993), Acs, Audretsch and Feldman (1992 and 1994), Audretsch and Feldman (1996) and Audretsch and Stephan (1996).

That knowledge spills over is barely disputed. In disputing the importance of knowledge externalities in explaining the geographic concentration of economic activity, Krugman (1991) and others do not question the existence or importance of such knowledge spillovers. In fact, they argue that such knowledge externalities are so important and forceful that there is no compelling reason for a geographic boundary to limit the spatial extent of the spillover. According to this line of thinking, the concern is not that knowledge does not spill over but that it should stop spilling over just because it hits a geographic border, such as a city limit, state line, or national boundary. The claim that geographic location is important to the process linking knowledge spillovers to innovative activity in a world of e-mail, fax machines and cyberspace may seem surprising and even paradoxical. The resolution to the paradox posed by the localisation of knowledge spillovers in an era where the telecommunications revolution has drastically reduced the cost of communication lies in a distinction between knowledge and information. Information, such as the price of gold on the New York Stock Exchange, or the value of the yen in London, can be easily codified and has a singular meaning and interpretation. By contrast, knowledge is vague, difficult to codify and often only serendipitously recognised. While the marginal cost of transmitting information across geographic space has been rendered invariant by the telecommunications revolution, the marginal cost of transmitting knowledge, and especially tacit knowledge, rises with distance.

Von Hipple (1994) demonstrates that high context, uncertain knowledge, or what he terms as sticky knowledge, is best transmitted via face-to-face interaction and through frequent and repeated contact. Geographic proximity matters in transmitting knowledge, because as Kenneth Arrow (1962) pointed out some three decades ago, such tacit knowledge is inherently non-rival in nature, and knowledge developed for any particular application can easily spill over and have economic value in very different applications. As Glaeser, Kallal, Scheinkman and Shleifer (1992, p. 1126) have observed, "intellectual breakthroughs must cross hallways and streets more easily than oceans and continents."

The importance of local proximity for the transmission of knowledge spillovers has been observed in many different contexts. It has been pointed out that, "business is a social activity, and you have to be where important work is taking place". ${ }^{6}$ A survey of nearly one thousand executives located in America's sixty largest metropolitan areas ranked Raleigh/Durham as the best city for knowledge workers and for innovative activity. ' The reason is that "A lot of brainy types who made their way to Raleigh/Durham were drawn by three top research universities US businesses, especially those whose success depends on staying at the top of new technologies and processes, increasingly want to be where hot new ideas are percolating. A presence in brain-power centres like Raleigh/Durham pays off in new products and new ways of doing business. Dozens of small biotechnology and software operations are starting up each year and growing like $k u d z u$ in the fertile climate."

Not only did Krugman (1991, p. 53) doubt that knowledge spillovers are not geographically constrained but he also argued that they were impossible to measure because "knowledge flows are invisible, they leave no paper trail by which they may be measured and tracked". However, an emerging literature (Jaffe, Trajtenberg and Henderson, 1993) has overcome data constraints to measure the extent of knowledge spillovers and link them to the geography of innovative activity. Jaffe (1989), Feldman (1994) and Audretsch and Feldman (1996) modified the model of the knowledge production function to include an explicit specification for both the spatial and product dimensions. Jaffe (1989) used the number of inventions registered with the United States patent office as a measure of innovative activity. By contrast, 
Audretsch and Feldman (1996) and Acs, Audretsch and Feldman (1992) developed a direct measure of innovative output consisting of new product introductions.

The consistent empirical evidence supports the notion knowledge spills over for third-party use from university research laboratories as well as industry R\&D laboratories. This empirical evidence suggests that location and proximity clearly matter in exploiting knowledge spillovers. Not only have Jaffe, Trajtenberg and Henderson (1993) found that patent citations tend to occur more frequently within the state in which they were patented than outside of that state, but Audretsch and Feldman (1996) found that the propensity of innovative activity to cluster geographically tends to be greater in industries where new economic knowledge plays a more important role. Prevenzer (1997) and Zucker, Darby and Armstrong (1994) show that in biotechnology, which is an industry based almost exclusively on new knowledge, the firms tend to cluster together in just a handful of locations. This finding is supported by Audretsch and Stephan (1996) who examine the geographic relationships of scientists working with biotechnology firms. The importance of geographic proximity is clearly shaped by the role played by the scientist. The scientist is more likely to be located in the same region as the firm when the relationship involves the transfer of new economic knowledge. However, when the scientist is providing a service to the company that does not involve knowledge transfer, local proximity becomes much less important.

There is reason to believe that knowledge spillovers are not homogeneous across firms. In analysing the role of spillovers for large and small enterprises separately, Acs, Audretsch and Feldman (1994) provide some insight into the puzzle posed by the recent wave of studies identifying vigorous innovative activity emanating from small firms in certain industries. How are these small, and frequently new, firms able to generate innovative output while undertaking generally negligible amounts of investment into knowledge generating inputs, such as $\mathrm{R} \& \mathrm{D}$ ? The answer appears to be through exploiting knowledge created by expenditures on research in universities and on R\&D in large corporations. Their findings suggest that the innovative output of all firms rises along with an increase in the amount of R\&D inputs, both in private corporations as well as in university laboratories. However, R\&D expenditures made by private companies play a particularly important role in providing knowledge inputs to the innovative activity of large firms, while expenditures on research made by universities serve as an especially key input for generating innovative activity in small enterprises. Apparently large firms are more adept at exploiting knowledge created in their own laboratories, while their smaller counterparts have a comparative advantage at exploiting spillovers from university laboratories.

In addressing the questions how and why knowledge spills over, an assumption implicit to the model of the knowledge production function is challenged - that firms exist exogenously and then endogenously seek out and apply knowledge inputs to generate innovative output. Although this may be valid some, if not most of the time, the evidence from biotechnology suggests that, at least in some cases, it is the knowledge in the possession of economic agents that is exogenous. In an effort to appropriate the returns from that knowledge, the scientist then endogenously creates a new firm. Thus, the spillover of knowledge from the source creating it, such as a university, research institute, or industrial corporation, to a new-firm start-up facilitates the appropriation of knowledge for the individual scientist(s) but not necessarily for the organisation creating that new knowledge in the first place (Audretsch and Stephan, 1996).

While Romer (1990 and 1994) and Krugman (1991) identified the role that knowledge spillovers and externalities play in generating endogenous growth, they are less precise about the actual mechanism by which knowledge spills over. Entrepreneurial small firms are one such mechanism transmitting the spillover of knowledge. Thus, an increase in the role of entrepreneurship activity may facilitate such knowledge spillovers and therefore subsequent growth. 


\section{Measuring entrepreneurial activity}

Operationalising entrepreneurship for empirical measurement is difficult (Storey, 1991). The degree of difficulty involved in measure increases exponentially when cross-country comparisons are involved. Studies focusing on a single country, either in a cross-sectional or time series context, have deployed a variety of proxy measures, spanning self-employment rates, business ownership rates, new-firm start-ups (births), as well as other measures of industry demography, such as turbulence (turnover), or the extent of simultaneous births and exits and net entry. Ideally, we would like to link each of these different measures reflecting a different aspect of entrepreneurship to growth at the country level. However, systematic measurement conducive to cross-country comparisons is limited.

International data on business owners per labour force (excluding agriculture) for 23 OECD countries are derived by EIM in The Netherlands from OECD and additional data sources. The number of business owners, as a share of the labour force, the "rate of entrepreneurship", is identified for each of these countries between 1974 and 1998. ${ }^{9}$ This measure is defined as the number of business owners (in all sectors excluding agriculture), divided by the total labour force. There are a number of important qualifications that should be emphasised when using and interpreting this measure. First, it lumps all types of a very heterogeneous activity across a broad spectrum of sectors and contexts into a solitary measure. This measure treats all businesses as the same, both high-tech and low-tech. Second, it is not weighted for magnitude or impact. Again, all businesses are measured identically, even though some clearly have a greater impact than others. Third, this variable measures the stock of businesses and not the start-up of new ones. Still, this measure has two significant advantages. The first is that, while not being a direct measure of entrepreneurship, it is a useful proxy for entrepreneurial activity (Storey, 1991). Second, it is measured and can be compared across countries and over time.

Data sources for this measure include the OECD Labour Force Statistics 1978-98. EIM completed the missing data by using ratios derived from various other sources. Furthermore, EIM made a unified data set of business owners as the definitions of business owners or self-employed in the OECD statistics are not fully compatible between countries. In some countries business owners are defined as individuals owning a business that is not legally incorporated. In other countries, owner/managers of an incorporated business (OMIBs) who gain profits as well as a salary are considered owners too. There are also countries who classify a part of the OMIBs as self-employed and another part as employee. This has to do with the way in which labour force surveys are set up in different countries. This topic is dealt with in Chapter 5 of the OECD Employment Outlook (June 2000). By and large, Australia, Japan, Norway and the United States use a narrow business ownership definition (excluding OMIBs or excluding most OMIBs), while the other countries apply a broader characterisation (including OMIBs or including most OMIBs). For the countries not following the broadest definition (including OMIBs), EIM made an estimation of the number of OMIBs using information derived from the European Observatory (KPMG, 2000), or, for the nonEuropean countries, using information from domestic sources. Another difference in definition is that for some countries unpaid family workers are included in the self-employment data as well. The unpaid family workers were eliminated from the data by using ratios from more recent years for which separate data on unpaid family workers are available. Finally, for countries where important trend breaks occur, these trend breaks were corrected for. Data on the labour force are also from the OECD Labour Force Statistics 1978-98. Again, some missing data have been filled in from various other sources.

Table 2 shows that the countries with the lowest rates of entrepreneurship in 1998 are Denmark, Luxembourg and Norway. These countries have in common that they are small and that the entrepreneurship rates are below 8\% in 1998. The sample average in 1994 is $11 \%$. There are two countries with an entrepreneurship rate in excess of $16 \%$ (Greece and Italy). Note that these are Mediterranean countries. The number of business owners in the 23 countries grew from about 30 million in 1974 to about 45 million in 1998. The proportional growth of the labour force has been lower in this period so that the rate of entrepreneurship increased, on average, from $10 \%$ to $11 \%$. 
Table 2. Entrepreneurship rates in 23 OECD countries, 1974-98

\begin{tabular}{|c|c|c|c|c|c|c|c|c|}
\hline \multirow[b]{2}{*}{ Country } & \multicolumn{3}{|c|}{ Level } & \multicolumn{2}{|c|}{ Growth (\%) } & \multicolumn{3}{|c|}{ Country share } \\
\hline & 1974 & 1986 & 1998 & $1986-74$ & $1998-86$ & 1974 & 1986 & 1998 \\
\hline Austria & 0.081 & 0.066 & 0.080 & -0.015 & 0.013 & 0.008 & 0.006 & 0.007 \\
\hline Belgium & 0.100 & 0.106 & 0.119 & 0.005 & 0.013 & 0.013 & 0.011 & 0.011 \\
\hline Denmark & 0.081 & 0.063 & 0.064 & -0.018 & 0.001 & 0.007 & 0.005 & 0.004 \\
\hline Finland & 0.062 & 0.066 & 0.082 & 0.004 & 0.015 & 0.005 & 0.004 & 0.005 \\
\hline France & 0.109 & 0.098 & 0.085 & -0.011 & -0.012 & 0.080 & 0.062 & 0.049 \\
\hline Germany (West) & 0.073 & 0.069 & 0.085 & -0.004 & 0.016 & 0.066 & 0.053 & 0.076 \\
\hline Greece* & 0.173 & 0.182 & 0.186 & 0.009 & 0.003 & 0.019 & 0.018 & 0.018 \\
\hline Ireland & 0.073 & 0.078 & 0.112 & 0.004 & 0.034 & 0.003 & 0.003 & 0.004 \\
\hline Italy & 0.144 & 0.167 & 0.182 & 0.023 & 0.015 & 0.095 & 0.098 & 0.095 \\
\hline Luxembourg* & 0.100 & 0.078 & 0.059 & -0.022 & -0.019 & 0.001 & 0.000 & 0.000 \\
\hline Netherlands & 0.097 & 0.082 & 0.104 & -0.015 & 0.022 & 0.019 & 0.014 & 0.018 \\
\hline Portugal $^{*}$ & 0.110 & 0.108 & 0.152 & -0.002 & 0.044 & 0.014 & 0.013 & 0.017 \\
\hline Spain & 0.116 & 0.115 & 0.130 & -0.001 & 0.015 & 0.051 & 0.042 & 0.048 \\
\hline Sweden & 0.071 & 0.066 & 0.082 & -0.005 & 0.016 & 0.009 & 0.008 & 0.008 \\
\hline United Kingdom & 0.077 & 0.089 & 0.109 & 0.012 & 0.020 & 0.066 & 0.065 & 0.070 \\
\hline Iceland & 0.102 & 0.099 & 0.132 & -0.004 & 0.033 & 0.000 & 0.000 & 0.000 \\
\hline Norway & 0.092 & 0.084 & 0.071 & -0.008 & -0.014 & 0.005 & 0.005 & 0.004 \\
\hline Switzerland & 0.065 & 0.070 & 0.091 & 0.005 & 0.021 & 0.008 & 0.007 & 0.008 \\
\hline United States & 0.082 & 0.103 & 0.103 & 0.021 & 0.000 & 0.252 & 0.319 & 0.319 \\
\hline Japan & 0.127 & 0.125 & 0.100 & -0.002 & -0.024 & 0.222 & 0.195 & 0.151 \\
\hline Canada & 0.075 & 0.100 & 0.141 & 0.025 & 0.041 & 0.025 & 0.035 & 0.049 \\
\hline Australia & 0.137 & 0.165 & 0.155 & 0.028 & -0.011 & 0.027 & 0.033 & 0.032 \\
\hline New Zealand & 0.098 & 0.110 & 0.142 & 0.012 & 0.032 & 0.005 & 0.005 & 0.006 \\
\hline Average & 0.098 & 0.100 & 0.111 & & & & & \\
\hline $\begin{array}{l}\text { Total business owners } \\
\text { in percentage }\end{array}$ & & & & & & 30337 & 38446 & 44027 \\
\hline
\end{tabular}

Note: The source of the data are OECD figures (which exclude agriculture), adapted by EIM to have improve upon international comparability. A star $\left(^{*}\right)$ for 1998 means provisional. Germany is West Germany for 1974 and 1986.

The United States is the country with the highest number of business owners. Nearly $32 \%$ of the total 45 million business owners in the 23 countries in 1998 are in the United States. Countries with a business ownership growth of more than three percentage points in the period of 1986 through 1998 are Canada, Iceland, Ireland, New Zealand and Portugal. Three of these five countries experienced a growth of the business ownership rate also in the previous period of 1974 through 1986. There are four countries suffering a decline in the business ownership rate in both periods: France, Luxembourg, Norway and Japan. The decline in Japan is particularly noteworthy since its share in total business owners dropped from more than $20 \%$ in 1974 to $15 \%$ in 1998 .

\section{Estimating the impact of entrepreneurship}

\section{Impact of entrepreneurship on growth ${ }^{10}$}

The previous section uses an index of entrepreneurial activity to find that the country experience has been heterogeneous over time. While some countries have experienced a considerable increase in 
entrepreneurial activity, others have experienced a reduction in the role of entrepreneurship. But this says nothing about the impact that these changes in the relative importance of entrepreneurship have on growth. In this section we examine the impact of changes in the relative importance of entrepreneurship on subsequent growth at the national level. In linking entrepreneurship to growth, it is important to move well beyond a simple correlation.

To link the degree of entrepreneurship to economic growth and control for country specific characteristics, Audretsch, Carree, van Stel and Thurik (2001) employ two modelling devices. The first is the assumption that a country's growth can be decomposed into two components - growth that would have occurred with an optimal degree of entrepreneurship (which is unknown and potentially specific to that particular country), and the impact on growth occurring from any actual deviations from that level of entrepreneurship. It is important to consider that each country has a broad range of characteristics that influence the optimal degree of entrepreneurship, many of which are not only unobservable, but also may be specific to that country. While the optimal degree of entrepreneurship might theoretically be the same in every country, there is no reason to impose such a restrictive assumption. In fact, differences in institutions, policies and history may contribute to each country having a different optimal degree of entrepreneurship. Thus, the less restrictive assumption is used here, which recognises that the optimal degree of entrepreneurship might, but must not, vary across countries.

The concept of "optimal industry structure" is deployed here not as a precise singular firm size, as Viner (1932), Kaldor (1934), and Lucas (1978) have done, but rather as a concept that recognises that an economy can have either too few or too many SMEs. This would suggest that the relationship between entrepreneurship and growth is certainly non-linear. Relying on the concept of "optimal" enables the recognition that, in fact, outside of a certain range of entrepreneurial activity, there may be either too many or too few entrepreneurial firms. This modelling device enables a focus on changes in the degree of entrepreneurship:

$$
\text { (1) } \Delta G N P_{c p}=\Delta G N P_{c p}^{*}-\gamma\left|S F P_{c p-1}-S F P_{c}^{*}\right| \text {, }
$$

where the dependent variable is the actual rate of economic growth. $\triangle G N P_{c p}^{*}$ is the rate of economic growth in country $c$ in the case where the actual industry structure $\left(S F P_{c p}\right)$ is at the optimal level at the start of the period $p$. For ease of exposition it is assumed that the optimal industry structure in a country remains constant for the total period under investigation. This is not vital to the analysis. Since only shortterm periods (maximum five years) are being considered this may be a reasonable assumption.

Industry structure is multidimensional and spans a broad array of characteristics that defy measurement by a single statistic. However, as explained elsewhere (Audretsch and Thurik, 1997 and 2001), the most salient characteristic driving the shift in industry structure from the managed to the entrepreneurial economy is that the relative role of entrepreneurial firms has increased. Thus, changes in industry structures are reflected by changes in the relative importance of entrepreneurial firms.

In equation (1) the parameter $\gamma$ is positive. Deviations of the actual industry structure from the optimal industry structure negatively affect economic growth, both when the industry structure consists of too few or too many small firms. In either case there is a deviation from the optimal industry structure and number of small firms. The second modelling technique we employ is to take the first difference of equation (1) to obtain:

$$
\text { (2) } \Delta G N P_{c p}=\Delta G N P_{c p-1}+\Delta \Delta G N P_{c p}^{*}-\gamma\left(\left|S F P_{c p-1}-S F P_{c}^{*}\right|-\left|S F P_{c p-2}-S F P_{c}^{*}\right|\right) .
$$


In case both $S F P_{c p-1}$ and $S F P_{c p-2}$ are above the optimal small-firm share, the expression between brackets reduces to $\triangle S F P_{c p-1}$. Indeed, in case the degree of entrepreneurship is too high, adding more entrepreneurship to the industry structure reduces economic growth. In case both $S F P_{c p-1}$ and $S F P_{c p-2}$ are below the optimal entrepreneurial firms share, the expression between brackets reduces to $-\triangle S F P_{c p-1}$. An increase in entrepreneurial firms when this presence is below optimal enhances economic performance. Therefore, the sign of the parameter of $\Delta S F P_{c p-1}$ reflects whether the degree of entrepreneurship is below or above the optimal levels for the countries under consideration. In case the parameter is negative, the industry structure consists of too many entrepreneurial firms. In case the parameter is positive, the reverse holds and the industry structure consists of too few entrepreneurial firms.

We will denote the parameter of $\Delta S F P_{c p-1}$ as $K$. Note that this is not the same parameter as $\gamma$, since the sign of $K$ is dependent on whether the actual entrepreneurial-firm share is above or below the optimal one. So, $\kappa$ can be both positive and negative whereas $\gamma$ is necessarily positive.

We make some further assumptions to transform equation (2) into an equation that can be estimated using the data at hand. First, we approximate $\Delta S F P_{c p-1}$ by $\Delta S F_{c p-1}-\Delta L F_{c p-1}$, the difference between the growth of entrepreneurial firms and large firms in terms of value-of-shipments. Second, we assume that $\Delta G N P_{c p}^{*}$ is idiosyncratic with respect to time and country. Therefore country dummies and time dummies (the last to correct for European wide business cycle effects) are included. Thus, $\triangle \triangle G N P_{c p}^{*}$ is approximated by time dummies only because the country dummies drop out when taking first differences. Third, we add an error term $e_{c p}$. Summarising we have:

$$
\text { (3) } \Delta G N P_{c p}=\Delta G N P_{c p-1}+\sum_{p=1}^{P} \beta_{p} D_{p}+\kappa\left(\Delta S F_{c p-1}-\Delta L F_{c p-1}\right)+e_{c p} \text {, }
$$

where $D_{p}$ denote dummy variables for periods $p=1, \ldots, P$. Factors specific to each time period are reflected by $\beta_{p}$. A high value of this parameter indicates an unexplained increase in the extent of economic growth. In case of a low $\beta_{p}$ the reverse holds. The contribution of the shift in the size class distribution of firms to the percentage growth of GNP is represented by $K$. The influence of this shift on GNP growth is lagged. This implies that $p=1, \ldots, P$ runs from 1990 through 1994 when applying equation (3) to our European data set.

To estimate equation (3), we use data provided by the European Observatory (EIM, 1993, 1994, 1995, 1996 and 1997). The European Observatory provides data on the annual percentage growth of real gross value added of the private sector, the annual percentage growth of value-of-shipments of small and medium-sized firms (with employment less than 200 employees), as well as the annual percentage growth of value-of-shipments of large firms (with employment of at least 200 employees). These data are available for five years (1989 through 1993) for all fifteen member countries of the European Union (Europe-15), Iceland, Norway and Switzerland (including Liechtenstein).

Hence, the European data set consists of a total of 90 (18 countries times five years) observations. However, Germany had to be omitted for the entire period. Germany's then recent unification led to specific economic perturbations that render it inappropriate for inclusion in the estimation model. The remaining 85 observations are used for computing the regression coefficients. The period 1990-94 is 
characterised by relatively vehement cyclical movements with 1992 being a recession year and 1994 being a year with an exceptional strong recovery.

In Table 3 the regression results for the period 1990-94 are presented. Equation (3) does not contain country dummies. The 'mean' country effect is reflected by coefficient $\alpha$ while $D_{1991}$ is left out of all computations to avoid full multicollinearity. ${ }^{11}$ The two dummy variables with a significant contribution are $D_{1993}$ and $D_{1994}$. This presumably reflects the strong economic recovery after the recession of 1992 . We present both results with all time dummies included and with the two insignificant dummies excluded. In the first part of Table 3 weighted least squares results are presented, with total employment as the weighting variable. In the second part of the table ordinary least squares results are presented.

Table 3. Regression results for impact of entrepreneurship on growth ${ }^{1,2}$

\begin{tabular}{|c|c|c|c|c|}
\hline \multirow[b]{2}{*}{$\alpha$} & \multicolumn{2}{|c|}{ Weighted least squares ${ }^{3}$} & \multicolumn{2}{|c|}{ Ordinary least squares } \\
\hline & -0.93 & -0.79 & -1.22 & -0.97 \\
\hline & $(-2.30)$ & $(-3.38)$ & $(-1.84)$ & $(-2.56)$ \\
\hline \multirow[t]{2}{*}{$\beta_{1990}$} & 0.52 & & 0.39 & \\
\hline & $(0.89)$ & & $(0.41)$ & \\
\hline \multirow[t]{2}{*}{$\beta_{1992}$} & -0.08 & & 0.37 & \\
\hline & $(-0.14)$ & & $(0.39)$ & \\
\hline \multirow[t]{2}{*}{$\beta_{1993}$} & 1.32 & 1.20 & 2.19 & 1.94 \\
\hline & $(2.26)$ & $(2.50)$ & $(2.32)$ & $(2.53)$ \\
\hline \multirow[t]{2}{*}{$\beta_{1994}$} & 4.35 & 4.25 & 4.72 & 4.48 \\
\hline & $(7.40)$ & $(8.74)$ & $(4.91)$ & $(5.65)$ \\
\hline \multirow[t]{2}{*}{$\kappa$} & 0.55 & 0.63 & 0.91 & 0.92 \\
\hline & $(2.14)$ & $(2.58)$ & $(2.20)$ & $(2.27)$ \\
\hline $\mathrm{R}^{2}$ & 0.441 & 0.422 & 0.318 & 0.317 \\
\hline Adjusted $\mathrm{R}^{2}$ & 0.406 & 0.401 & 0.275 & 0.291 \\
\hline DW & 2.05 & 2.04 & 1.72 & 1.72 \\
\hline $\mathrm{N}$ & 85 & 85 & 85 & 85 \\
\hline
\end{tabular}

In each of the cases we find a significantly positive coefficient (at the 5\% significance level) for $K$. Its value ranges from 0.55 for the first column of Table 3 to 0.92 for the last column.

The empirical evidence suggests that an increased role of entrepreneurial activity results in higher subsequent rates of growth. However, this result is qualified by the large standard deviation of the coefficient for $K$. Another important qualification to these results is that measurement of the variables includes a number of estimates. Follow-up studies are required for corroboration of these results. ${ }^{12}$ Still, $K$ is found to be significantly positive in all computations. We conclude that, based on the empirical findings, there is evidence that those countries that have experienced an increased role of entrepreneurial activity have also experienced higher rates of subsequent growth, at least for a sample of Western European countries over a recent time period. Since our interpretation is that this shift is an indicator of the stage of the transition of the economy from a managed one to an entrepreneurial one, we conclude that European countries that progress on this transition track seem to have been rewarded with additional growth. 


\section{DSTI/DOC(2001)2}

One has to be careful interpreting the estimation results for different countries. The estimated positive value of $K$ must be viewed as an average value of the (unobserved) $\kappa_{c}$ 's of the different countries. So, the positive value found for $K$ does not mean that in all countries in the sample an increase in small-firm presence is rewarded with additional growth. There may be countries in the sample where small-firm presence is indeed above the optimal level and consequently, a further increase in the number of small firms leads to a growth penalty instead of a growth reward. The estimation results do imply, however, that for the majority of countries in the sample, the number of small firms was too low in the period under consideration. In translating the positive value of $K$ in terms of implications for different countries, policy makers should compare small-firm presence in their own country with that in surrounding countries. If $S F P$ is relatively low, small-firm presence is expected below optimum, given the positive value of $K$. On the other hand, if $S F P$ is relatively high, small-firm presence is not necessarily below optimum, despite the estimated $K$ being positive.

The regression results are illustrated using Figure 1. We have grouped the growth-acceleration observations, $\Delta \Delta G N P=\Delta G N P_{c p}-\Delta G N P_{c p-1}$, on the basis of the degree to which the value-of-shipments shifted from large to small firms. That is, the $\triangle \Delta G N P$ observations have been sorted in order of the values of the (lagged) structural change variable, $\Delta S F-\Delta L F$. Both variables have been computed in deviation of the mean per year in order to correct for specific year effects. The 85 observations have been divided in 5 groups of 17 observations. The averages of both $\Delta S F-\Delta L F$ and $\Delta \Delta G N P$ are displayed in Figure 1. We see that, on average, an increased role of entrepreneurial activity is associated with a higher growth acceleration. Existing growth differences between countries do not disappear because of a change in the relative role of entrepreneurship, at least not in a period as short as our regression period. The derivation of our regression equation (3) shows that we have assumed optimal growth $\triangle G N P^{*}$ to be idiosyncratic per country. However, the changes in the relative role of entrepreneurship do affect growth rates within countries and this is exactly what is illustrated by the sorted growth acceleration averages in Figure 1. We have grouped the growth-acceleration observations, $\Delta \Delta G N P=\Delta G N P_{c p}-\Delta G N P_{c p-1}$, on the basis of the degree to which the value-of-shipments shifted from large to small firms. That is, the $\Delta \triangle G N P$ observations have been sorted in order of the values of the (lagged) structural change variable, $\Delta S F-\Delta L F$. Both variables have been computed in deviation of the mean per year in order to correct for specific year effects. The 85 sorted observations have been divided into five groups of 17 observations. The averages of both $\Delta S F-\Delta L F$ and $\Delta \Delta G N P$ are displayed in Figure 1. We see that, on average, a larger shift toward smallness is associated with a higher growth acceleration.

An important qualification of this statistical analysis is that the type or quality of the entrepreneurial activity is not taken into consideration. In fact, certain types of entrepreneurship, such as knowledge-based or science-based entrepreneurship should have a greater impact on growth than unskilled entrepreneurial activities. The analyses reported here do not incorporate the heterogeneous nature of entrepreneurship. An important area for future research is to focus more explicitly on how different types of entrepreneurial activities have differential impacts on growth activities. 
Figure 1. Impact of changes in entrepreneurship on growth ${ }^{1}$

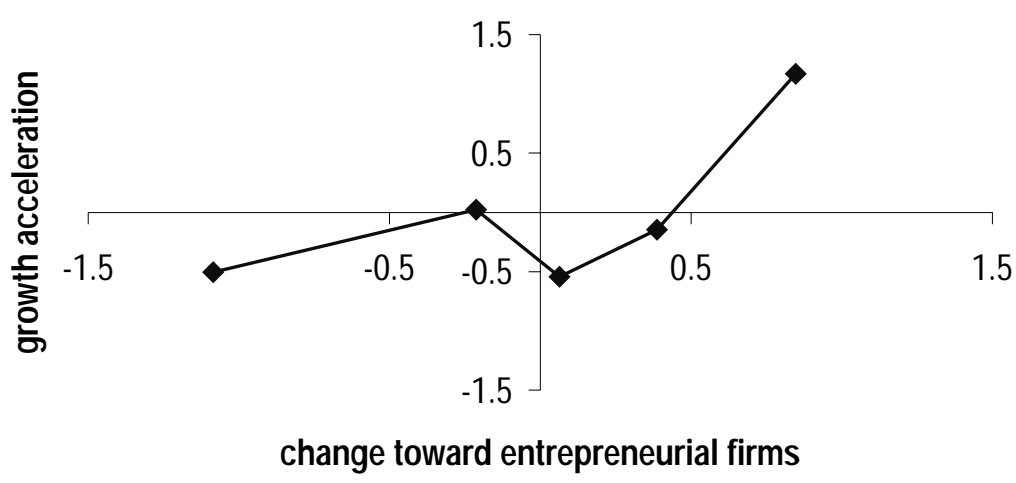

1. Averages of five groups of growth acceleration values, grouped on the basis of the degree of change towards small firms, in deviation of means per year.

\section{Impact of entrepreneurship on unemployment ${ }^{13}$}

There are several additional limitations associated with the above analysis. These qualifications involve the measure of entrepreneurship, the countries included in the analysis, the time period, and even the measure of growth. After all, the emergence of the concept of jobless growth in recent years in policy debates reflects the value of not just growth per se, but also growth that results in the reduction of unemployment as an explicit policy goal. Thus, in this second analysis, a different measure of entrepreneurship is used, along with a longer time period that extends until 1998 to identify the impact of reductions in unemployment.

Why should an increased amount of entrepreneurship impact unemployment? One answer is implicit in what has become known as Gibrat's Law. The assumption underlying Gibrat's Law is that firm growth is independent of size. Sutton (1997, p. 43), interprets "Gibrat's Legacy", as "The probability that the next opportunity is taken up by any particular active firm is proportional to the current size of the firm." An important implication of Gibrat's Law is that shifting employment from large to small enterprises should have no impact on total employment, since the expected growth rates of both types of firms are identical. Thus, a restructuring of the economy away from large enterprises and towards small firms, should have not impact on the unemployment rate.

However, there is strong and systematic empirical evidence suggesting that, in fact, Gibrat's Law, does not hold across a broad spectrum of firm sizes. Three comprehensive and exhaustive compilations (Sutton, 1997; Geroski, 1994; and Caves, 1998) of studies relating firm size to growth have produced what Geroski (1995) terms as a stylised fact that smaller firms have higher growth rates than their larger counterparts. A central finding of this literature is that firm growth is negatively related to firm size and age. These findings have been confirmed in virtually every subsequent study undertaken, despite differences in country, time period, industry, and methodology used.

Thus, if the growth rates of smaller firms systematically exceed those of their larger counterparts, restructuring economic activity away from large firms and towards new and small firms should not result in a neutral impact on employment. Rather, the higher growth rates of small firms, should result in lower unemployment rates. 
Formally, this can be shown by starting with the basic structure used to test Gibrat's Law, which relates the employment size, $\mathrm{E}$, of firm I at time $\mathrm{t}-1$, to growth in period $\mathrm{t}$ :

(4) $\ln \left(E_{i t}\right)-\ln \left(E_{i, t-1}\right)=a-b \ln \left(E_{i, t-1}\right)$

where $b>0$, which implies:

(5) $E_{i t}=e^{a} E_{i, t-1}^{1-b}$

Firms do not change size only in the case $E_{i t-1}=e^{a / b}$

Assume that the labour force equals $L$ and that there are $M$ large firms. These variables are assumed not to change over time. Workers can either be employed by a small firm (i.e. managed by an entrepreneur) by a large firm, or be unemployed:

(6) $L=N_{t} s_{t}+M r_{t}+U_{t}$

where $N_{t}$ is the number of entrepreneurs, $s_{t}$ is the number of employees employed by them, $r_{t}$ is the number of employees at large firms and $U_{t}$ is the number of unemployed. We assume that in the first period the number of employees at small firms is below the size at which firms do not change size while the number of employees at large firms is above this level, or $s_{1}<e^{a / b}<r_{1}$.

To analyse the impact of restructuring we consider two regimes. In the first, or the Routinised Regime, it is assumed there is no exit or start-up of new firms, so that the composition of firms remains constant over time. In the second, or the Entrepreneurial Regime, it is assumed that a certain percentage of largefirm employees spin-off from their employers and start new firms (which are small). ${ }^{14}$

In the first regime, which precludes the possibility of start-ups via large-firm spin-offs, the levels of unemployment in the subsequent two periods can be computed as:

$$
\begin{aligned}
& \text { (7) } U_{2}=L-N_{1} s_{2}-M r_{2}=L-N_{1} e^{a} s_{1}^{1-b}-M e^{a} r_{1}^{1-b} \\
& \text { (8) } U_{3}=L-N_{1} s_{3}-M r_{3}=L-N_{1} e^{a} e^{a(1-b)} s_{1}^{(1-b)^{2}}-M e^{a} e^{a(1-b)} r_{1}^{(1-b)^{2}}
\end{aligned}
$$

In the second, or Entrepreneurial Regime, a fraction of workers leave the incumbent large firms to start a new firm. These new start-ups attain the same size as the incumbent small firms $\left(s_{1}\right)$. The unemployment levels in the Entrepreneurial Regime are therefore:

(7') $U_{2}^{\prime}=L-N_{2} s_{2}-M r_{2}=L-N_{2} e^{a} s_{1}^{1-b}-M e^{a}\left(r_{1}-\left(N_{2}-N_{1}\right) s_{1} / M\right)^{1-b}$

$$
U_{3}^{\prime}=L-N_{2} s_{3}-M r_{3}=L-N_{2} e^{a} e^{a(1-b)} s_{1}^{(1-b)^{2}}-M e^{a} e^{a(1-b)}\left(r_{1}-\left(N_{2}-N_{1}\right) / M s_{1}\right)^{(1-b)^{2}}
$$

The difference between the change in unemployment between the Entrepreneurial and Routinised Regimes is: 


$$
\begin{aligned}
& \text { (9) } U_{3}^{\prime}-U_{2}^{\prime}-\left(U_{3}-U_{2}\right)=\left(N_{2}-N_{1}\right) e^{a}\left(s_{1}^{1-b}-e^{a(1-b)} s_{1}^{(1-b)^{2}}\right)+ \\
& M e^{a}\left\{\left(r_{1}-\left(N_{2}-N_{1}\right) s_{1} / M\right)^{1-b}-r_{1}^{1-b}+e^{a(1-b)}\left(r_{1}^{(1-b)^{2}}-\left(r_{1}-\left(N_{2}-N_{1}\right) s_{1} / M\right)^{(1-b)^{2}}\right)\right\}
\end{aligned}
$$

This difference is always negative, which suggests that shifting economic activity away from large enterprises towards smaller firms should result in lower unemployment.

The panel data set of unemployment and self-employment rates for the 23 OECD countries over the 1974-98 period is constructed as follows. For the unemployment data we use the standardised unemployment rate of the OECD Main Economic Indicators (2000). The data for self-employment are retrieved from the Compendia 2000.1 data set of EIM in Zoetermeer, The Netherlands. The Compendia data set uses data from the OECD Labour Force Statistics and other (country-specific) sources to make the self-employment data as comparable as possible across countries. An important aspect of this is to try to have an identical measure of self-employed for each of the OECD countries.

To test the hypothesis that an increase in entrepreneurial activity leads to a decrease in subsequent unemployment we estimate the following equation:

(10) $U N_{t}-U N_{t-1}=\alpha+\beta\left(S E_{t-1}-S E_{t-2}\right)+\gamma\left(U N_{t-1}-U N_{t-2}\right)+\varepsilon_{1 t}$

where the expected sign of the coefficient B is negative.

Using the panel data set consisting of 23 OECD countries between 1974-1998, Equation (10) is estimated using weighted least squares and the results shown in Table 4 . The weighting variable is the number of self-employed. The models are estimated for three different time spans, four years, eight years and 12 years, in order to gain insight on the lag structures between unemployment and self-employment. A longer lag structure of at least eight years is more compelling because the employment impact of new startups is not instantaneous but rather requires a number of years for the firm to grow. As Geroski (1995, p. 148), "Even successful entrants may take more than a decade to achieve a size comparable to the average incumbent." Audretsch (1995) shows that share of total employment accounted for by a cohort of new-firm start-ups in US manufacturing more than doubles as the firms age from two to six years old (no evidence was provided beyond six years).

Table 4. Regression results for the impact of changes in entrepreneurship on unemployment

\begin{tabular}{lclll}
\hline Variable & Parameter & 4 years & 8 years & 12 years \\
\hline Constant & $\alpha$ & 0.005 & 0.004 & 0.008 \\
& & $(2.0)$ & $(1.0)$ & $(0.9)$ \\
$S E_{t-1}-S E_{t-2}$ & $\beta$ & -0.312 & -0.779 & -0.843 \\
& & $(1.0)$ & $(2.6)$ & $(2.1)$ \\
$U N_{t-1}-U N_{t-2}$ & $\gamma$ & -0.197 & -0.182 & -0.176 \\
R-squared & & $(2.1)$ & $(2.1)$ & $(1.4)$ \\
Observations & & 0.04 & 0.22 & 0.28 \\
& & 115 & 46 & 23
\end{tabular}

Note: Absolute t-values between brackets. The results are from a weighted least squares regression with the weighting variable being the number of self-employed eight years before. 


\section{DSTI/DOC(2001)2}

When a four-year time span is used in Table 4, the explanatory power is low. However, when the longer time spans of 8- and 12-years are used, changes in self-employment are found to reduce subsequent unemployment. These results are consistent with those found in the previous section using a different measure of entrepreneurship, more limited sample of countries and more restricted time period. Thus, the results from these two types of analyses consistently point to a positive link between an increased role of entrepreneurship and greater subsequent growth. The empirical evidence is robust between these two approaches using: i) different measures of entrepreneurship; ii) different samples of OECD countries; iii) different time periods; and $i v$ ) different measures of economic performance.

\section{Policy implications}

One of the central goals of public policy common among all OECD countries is the generation of growth, and especially the creation of employment. Much of the policy debate to generate growth and jobs has relied on a macroeconomics framework and focused on traditional the traditional macroeconomic policy instruments. The results of this paper suggest that a different, less traditional instrument for generating growth and employment plays an important role in the OECD - policies that generate and promote entrepreneurship (Audretsch et al., 2001). Based on two different statistical analyses, the empirical evidence for a panel of OECD countries clearly suggests that those countries that have experienced an increase in entrepreneurial activity have also enjoyed higher rates of growth and greater reductions in unemployment. By contrast, those countries that have not increased the degree of entrepreneurial activity have had less growth and less reductions in unemployment.

This paper is among the first to link entrepreneurship to growth. While the statistical evidence provides compelling support for such a link, the actual mechanisms why entrepreneurship generates growth are less obvious. To interpret these results, this paper relies on a rich body of literature, both theoretical and empirical, analysing the microfoundations of entrepreneurship. Entrepreneurship generates growth because it serves as a vehicle for innovation and change, and therefore as a conduit for knowledge spillovers. Thus, in a regime of increased globalisation, where the comparative advantage of OECD countries is shifting towards knowledge-based economic activity, not only does entrepreneurship play a more important role, but the impact of that entrepreneurship is to generate growth.

As the comparative advantage in Western Europe and North America has become increasingly based on new knowledge, public policy towards business has responded in two fundamental ways. The first has been to shift the policy focus away from the traditional triad of policy instruments essentially constraining the freedom of firms to contract - regulation, competition policy or antitrust, and public ownership of business. The policy approach of constraint was sensible as long as the major issue was how to restrain footloose multinational corporations in possession of considerable market power. This is reflected by the waves of deregulation and privatisation along with the decreased emphasis of competition policy throughout the OECD. Instead, a new policy approach emerges which focuses on enabling the creation and commercialisation of knowledge. Examples of such policies include encouraging $R \& D$, venture capital and new-firm start-ups.

The second fundamental shift involves the locus of such enabling policies, which are increasingly at the state, regional or even local level. The downsizing of federal agencies charged with the regulation of business in the United Sates has been interpreted by many scholars as the eclipse of government intervention. But to interpret deregulation, privatisation and the increased irrelevance of competition policies as the end of government intervention in business ignores an important shift in the locus and target of public policy. The last decade has seen the emergence of a broad spectrum of enabling policy initiatives that fall outside of the jurisdiction of the traditional regulatory agencies. Sternberg (1996) documents how the success of a number of different high-technology clusters spanning a number of developed countries is the direct result of enabling policies, such as the provision of venture capital or research support. There is 
evidence that the amount of venture capital available to new-firm start-ups in high-technology industries in Germany is dramatically increasing. The amount of venture capital provided by direct-investment and venture capital programs sponsored by the Federal Ministry for Education, Science, Research and Technology (BMBF) has increased from about DEM 10 million in 1989 to more than DEM 458 million in 1997 (BMBF, 1996).

Indirect promotion of new technology-based firms (NTBFs) by the federal government has risen from DEM 45.9 million in 1991 to almost DEM 82 million in 1993 (BMBF, 1996, p.97). Similarly, Sternberg (1996) has shown that a number of government-sponsored technology policies has triggered the start-up of new firms. The majority of the start-up programs are targeted towards eliminated particular bottlenecks in the development and financing of new firms. Sternberg (1990) examines the impact that 70 innovation centres have had on the development of technology-based small firms. He finds that the majority of the entrepreneurs find a number of advantages from locating at an innovation centre.

The Kreditanstalt fur Wiederaufbau (KfW), or German Reconstruction Bank has been one of the most important institutions promoting SMEs in Germany. The KfW provides financial support for around 20000 SMEs each year. Of these firms, 80\% have sales less than DEM 10 million. The support of SMEs by the KfW resulted in the creation of nearly 150000 jobs in 1992 and 40000 jobs in 1995 . Similarly, the Bundesministerium fur Bildung, Wissenschaft, Forschung und Technologie (BMBF) has had a series of programs to promote German SMEs.

One of the most interesting examples of the strategic management of regions involves the establishment of five EXIST regions in Germany, where start-ups from universities and government research laboratories are encouraged (BMBF, 2000). The programme has the explicit goals of: $i$ ) creating an entrepreneurial culture; ii) the commercialisation of scientific knowledge; and iii) increasing the number of innovative start-ups and SMEs. Five regions were selected among many applicants for START funding. These are: $i$ ) the Rhein-Ruhr region (bizeps programme); ii) Dresden (Dresden exists); iii) Thueringen (GET UP); iv) Karlsruhe (KEIM); and v) Stuttgart (PUSH!).

These programmes promoting entrepreneurship in a regional context are typical of strategic entrepreneurial policy. While these entrepreneurial policies are evolving, they are clearly gaining in importance and impact in the overall portfolio of economic policy instruments.

For example, the Advanced Research Program in Texas has provided support for basic research and the strengthening of the infrastructure of the University of Texas, which has played a central role in developing a high-technology cluster around Austin (Feller, 1997). The Thomas Edison Centres in Ohio, the Advanced Technology Centres in New Jersey, and the Centres for Advanced Technology at Case Western Reserve University, Rutgers University and the University of Rochester have supported generic, precompetitive research. This support has generally provided diversified technology development involving a mix of activities encompassing a broad spectrum of industrial collaborators.

Such enabling policies that are typically implemented at the local or regional level are part of a silent policy revolution currently underway. The increased importance of innovative regional clusters as an engine of economic growth has led policy makers to abandon the policy cry frequently heard two decades ago, "Should we break up, regulate, or simply take over General Motors, IBM and US Steel" for a very different contemporary version: "How can we grow the next Silicon Valley?"

One of the most important and significant institutional changes promoting entrepreneurship in Germany has been the creation of a new stock market listing high-tech start-ups, Der Neue Markt (New Market), which is a stock market for high-growth and innovative firms, started in 1997. With over 300 listed firms, the Neue Markt segment is the leading growth market and by far the leading Initial Public Offering (IPO) platform in Europe. The large number of new issues from Germany and abroad, as well as 
the market capitalisation, stock-exchange turnover and issue volumes, have made 1999 a record year for the Neuer Markt. The number of potential IPOs from other countries is still high, with a large number of inquiries, from France and the United Kingdom, and especially from the United States. A special feature of Der Neue Markt is the high concentration of start-ups in ten sectors. They comprise Biotechnology, Financial Services, Industrials \& Industrial Services, Internet, IT Services, Media \& Entertainment, MedTech \& Health Care, Software, Technology and Telecommunications.

Another important policy instrument to promote entrepreneurship at the national level has been the Small Business Innovation Research (SBIR) programme. The SBIR was enacted by the United States Congress in 1984. The programme provides a mandate that each participating government agency must spend a share of its research budget on contracts to small firms. This includes the major federal agencies, such as the Department of Defence, the National Institutes of Health, the National Science Foundation, Department of Energy and the National Aeronautics and Space Administration. The Small Business Innovation Development Act of $1982,{ }^{15}$ required that agencies with extramural $R \& D$ budgets of USD 100 million or more set aside not less than $0.2 \%$ of that amount for the SBIR programme. In addition, the Act provided for annual increases up to a ceiling of not less than $1.25 \%$ of the agencies' budgets. The amount of awards will total over USD 1.4 billion in 1999.

The SBIR consists of three phases. Phase I is oriented towards determining the scientific and technical merit along with the feasibility of a proposed research idea. Phase II extends the technological idea and emphasises commercialisation. Phase II involves additional private funding for the commercial application of a technology. Under the Small Business Research and Development Enhancement Act of 1992, funding in Phase I was increased to USD 100 000, and in Phase II to USD 750000 (Wessner, 2000).

The SBIR was an offshoot of the Small Business Investment Company (SBIC) programme, which provided more than USD 3 billion to young firms between 1958 and 1969. During this period, this support amounted to more than three times the total amount of private venture capital.

The SBIR represents about $60 \%$ of all public SME finance programmes. Taken together, the public SME finance is about two-thirds as large as private venture capital. In 1995, the sum of equity financing provided through and guaranteed by public programmes financing SMEs was USD 2.4 billion, which amounted to more than $60 \%$ of the total funding disbursed by traditional venture funds in that year. Equally as important, the emphasis on SBIR and most public funds is on early-stage finance, which is generally ignored by private venture capital. Some of the most innovative American companies received early-stage finance from SBIR, including Apple Computer, Chron, Compaq and Intel.

While systematic evidence has been compiled indicating that SMEs receiving SBIR support exhibit greater rates of growth than those that do not, there is also evidence suggesting that the SBIR alters the career choices of scientists and engineers. In particular, the evidence suggests that:

- A significant number of the firms would not have been started in the absence of SBIR.

- A significant number of the scientists and engineers would not have become involved in the commercialisation process in the absence of SBIR.

- A significant number of other firms are started because of the demonstration effect by the efforts of scientists to commercialise knowledge.

- As a result of the demonstration effect by SBIR funded commercialisation, a number of other scientists alter their careers to include commercialisation efforts. 
- Technology-based entrepreneurs start firms because they have ideas that they think are potentially valuable; they do not start firms and then search for useful ideas or products. This is reflected by the fact that not a single respondent on either the survey or from the case studies suggested that they would have tried to start the firm with a different idea in the absence of SBIR funding. However, once the firm exists, one-quarter of the respondents and one-sixth of the case studies indicated that they would have tried to continue the firm with a different idea in the absence of SBIR funding. These different results may suggest that the SBIR has a greater impact on commercialising ideas that otherwise would not find their way into the market on potential entrepreneurs than on existing small firms.

\section{Conclusions}

Globalisation combined with the telecommunications revolution has drastically reduced the cost of transporting not just material goods but also information across geographic space. High wages are increasingly incompatible with information-based economic activity, which can be easily transferred to a lower cost location. By contrast, the creation of new ideas based on tacit knowledge cannot easily be transferred across distance. Thus, the comparative advantage of the high-cost countries in the OECD is increasingly based on knowledge-driven innovative activity. The spillover of knowledge from the firm or university creating that knowledge to a third-party firm is essential to innovative activity. Such knowledge spillovers tend to be spatially restricted. Thus, an irony of globalisation is that even as the relevant geographic market for most goods and services becomes increasingly global, the increased importance of innovative activity in the leading developed countries has triggered a resurgence in the importance of small entrepreneurial firms as the locomotive for competitiveness and growth. As knowledge increases in importance as a source of international competitiveness, so does the role of small entrepreneurial firms. This paper has provided evidence linking economic performance, in terms of both growth and reduction of unemployment, to an increased role of entrepreneurial activity.

Measuring entrepreneurial activity, especially in a cross-country context, is elusive and fraught with limitations. This paper offers two distinct approaches, based on two different measures of entrepreneurship - the relative share of economic activity accounted for by small firms, and the selfemployment rate. In addition, two different measures of performance of economic activity are also analysed - economic growth and reduction of unemployment - to link changes in entrepreneurship to changes in economic performance. Different samples including OECD countries over different time periods reach consistent results - increases in entrepreneurial activity tends to result in higher subsequent growth rates and a reduction of unemployment.

These results are instructive, because public policy throughout the OECD countries has been preoccupied with generating economic growth and reducing unemployment. The resulting policy debate has typically focused on macroeconomic policies and instruments. The results of this paper suggest that an additional set of instruments may also be valuable in generating growth and reducing unemployment policies enabling the start-up and viability of entrepreneurial small firms. As the evidence shows, just as countries reluctant to shift their industry structures towards smaller entrepreneurial enterprises will be penalised by lower growth rates and higher unemployment, those nations able to harness the forces of technology and globalisation by facilitating entrepreneurial activity are rewarded by growth dividends and reduced unemployment. 


\section{NOTES}

1. “The Death of Distance”, The Economist, 30 September, 1995.

2. "Indicator Data Sources", in The New Economy Index, http://www.dlcppi.org/ppi.org/ppi/tech/neweconomy_site/sources.html (accessed June 1999).

3. The data are adopted from Jensen (1993).

4. "Markets Go Global”, The Economist, 20 September, 1997.

5. See Audretsch (1995).

6. “The Best Cities for Knowledge Workers”, Fortune, 15 November, 1993, p. 44.

7. The survey was carried out in 1993 by the management consulting firm of Moran, Stahl \& Boyer of New York City.

8. “The Best Cities for Knowledge Workers", Fortune, 15 November, 1993, p. 44.

9. Contact André van Stel of EIM for further information about these data (ast@eim.nl). The data set is referred to as COMPENDIA 2000.1

10. This section relies heavily on analyses taken from Audretsch, Carree, van Stel and Thurik (2001).

11. Therefore, instead of estimating coefficients for all $P$ time dummies as suggested by equation (3), we actually estimate $P-1$ dummy coefficients and a constant term $\alpha$.

12. Carree and Thurik (1998, 1999 and 2000) provide complementary analyses showing the consequence of lagging behind in this restructuring process in manufacturing. Using a sample of 14 manufacturing industries in 13 European countries and 13 manufacturing industries in 12 European countries, respectively, they find that, on average, the employment share of large firms in 1990 has had a negative effect on growth of output in the subsequent four-year period. Thurik (1996) shows that the percentage growth of GNP is explained using a structural shift. This shift is captured by the difference between the annual percentage growth of value-of-shipments of large firms (with employment of at least 500 employees) and the annual percentage growth of value-of-shipments of small firms (with employment of less than 500 employees), using data for three distinct time periods: 1988-90, 1989-92 and 1990-93 for all twelve old member countries of the European Union.

13. This section relies heavily on analyses taken from Audretsch, Carree, van Stel and Thurik (2001).

14. The concepts of the Routinised and Entrepreneurial Regimes correspond somewhat with those introduced by Winter (1984) and operationalised by Audretsch (1995).

15. Public Law 97-219, 22 July 1982. 


\section{REFERENCES}

Acs, Z.J. and D.B. Audretsch (1990), Innovation and Small Firms, MIT Press, Cambridge.

Acs, Z.J. and D.B. Audretsch (1993), Small Firms and Entrepreneurship: An East-West Perspective, Cambridge University Press, Cambridge, pp. 227-231.

Acs, Z.J., D.B. Audretsch and M.P. Feldman (1992), "Real Effects of Academic Research", American Economic Review, 82(1), pp. 363-367.

Acs, Z.J., D.B. Audretsch and M.P. Feldman (1994), "R\&D Spillovers and Recipient Firm Size", Review of Economics and Statistics, 100(2), pp. 336-367.

Almeida, P. and B. Kogut (1997), "The Exploration of Technological Diversity and the Geographic Localisation of Innovation”, Small Business Economics, 9(1), pp. 21-31.

Arrow, K. (1962), "Economic Welfare and the Allocation of Resources for Invention", in R. Nelson (ed.), The Rate and Direction of Inventive Activity, Princeton University Press, Princeton.

Audretsch, D. and A. Thurik (eds.) (1999), Innovation, Industry Evolution and Employment, Cambridge University Press, Cambridge.

Audretsch, D. and A. Thurik (2001), "What's New about the New Economy? Sources of Growth in the Managed and Entrepreneurial Economies", Industrial and Corporate Change, 10(1), pp. 267-315.

Audretsch, D. and M. Feldman (1996), "R\&D Spillovers and the Geography of Innovation and Production", American Economic Review, 86(4), pp. 253-273.

Audretsch, D. and P. Stephan (1996), "Company-Scientist Locational Links: The Case of Biotechnology", American Economic Review, 86(4), pp. 641-652.

Audretsch, D. (1995), Innovation and Industry Evolution, MIT Press, Cambridge, MA.

Audretsch, D., W. Baumol and A. Burke (2001), "Competition Policy in Dynamic Markets", International Journal of Industrial Organization, 19(5), pp. 613-634.

Audretsch, D.B., G. van Leeuwen, B. Menkveld and R. Thurik (2001), "Market Dynamics in the Netherlands: Competition Policy and the Role of Small Firms", International Journal of Industrial Organization, 19(5), April, pp. 611-862.

Audretsch, D.B., M.A. Carree, A.J. van Stel and A.R. Thurik (2000), "Impeded Industrial Restructuring: The Growth Penalty", Centre for Economic and Policy Research Discussion Paper.

Audretsch, D.B., M.A. Carree and A.R Thurik (2001), "Entrepreneurship and Unemployment", Institute for Development Strategies Discussion Paper, Indiana University. 


\section{DSTI/DOC(2001)2}

Baily, Martin Neil, Eric J. Bartelsman and John Haltiwanger (1996), "Downsizing and Productivity Growth: Myth or Reality?", Small Business Economics, 8(4), August, pp. 259-278.

Berman, Eli, John Bound and Stephen Machin (1997), "Implications of Skill-Biased Technological Change: International Evidence", Working Paper No. 6166, National Bureau of Economic Research (NBER), Cambridge, MA.

BMWi (Federal Ministry of Economics and Technology) (2000), Economic Report'99, Federal Ministry of Economics and Technology, Bonn.

Carree, M.A. and L. Klomp (1996), "Small Business and Job Creation: A Comment", Small Business Economics 8, pp. 317-322.

Carree, M.A. (1997), Market Dynamics, Evolution and Smallness, Thesis Publishers \& Tinbergen Institute, Amsterdam.

Caves, Richard E. (1998), "Industrial Organization and New Findings on the Turnover and Mobility of Firms", Journal of Economic Literature, 36(4), December, pp. 1947-1982.

Chandler, A.D. Jr. (1990), Scale and Scope: The Dynamics of Industrial Capitalism, Harvard University, Cambridge.

Cohen, W.M. and S. Klepper (1992), "The Trade-off between Firm Size and Diversity in the Pursuit of Technological Progress", Small Business Economics 4, pp. 1-14.

Davis, Steven J., John Haltiwanger and Scott Schuh (1996), Job Creation and Destruction, MIT Press, Cambridge.

Davis, Steven J., John Haltiwanger and Scott Schuh (1996), "Small Business and Job Creation: Dissecting the Myth and Reassessing the Facts", Small Business Economics, 8(4), August, pp. 297-315.

Dosi, G. (1988), "Sources, Procedures and Microeconomic Effects of Innovations", Journal of Economic Literature 26, pp. 1120-1171.

EIM (1993), European Observatory: First Annual Report, Zoetermeer, The Netherlands.

EIM (1994), European Observatory: Second Annual Report, Zoetermeer, The Netherlands.

EIM (1995), European Observatory: Third Annual Report, Zoetermeer, The Netherlands.

EIM (1996), European Observatory: Fourth Annual Report, Zoetermeer, The Netherlands.

EIM (1997), European Observatory: Fifth Annual Report, Zoetermeer, The Netherlands.

Ellsion, G. and E. Glaeser (1997), "Geographic Concentration in US Manufacturing Industries: A Dartboard Approach", Journal of Political Economy 4, pp. 889-927.

EUROSTAT (1994), Enterprises in Europe, Third Edition, Luxembourg.

EUROSTAT (1996), Industrial Trends Monthly Statistics 1996/6, Luxembourg. 
Evans, David and Boyan Jovanovic (1989), "Estimates of a Model of Entrepreneurial Choice under Liquidity Constraints", Journal of Political Economy, 97(3), pp. 808-827.

Evans, David and Linda S. Leighton (1990), "Small Business Formation by Unemployed and Employed Workers", Small Business Economics, 2(4), pp. 319-330.

Feller, Irwin (1997), "Federal and State Government Roles in Science and Technology", Economic Development Quarterly, 11(4), pp. 283-296.

Geroski, Paul A. (1995), "What Do We Know About Entry?", International Journal of Industrial Organization (Special Issue on The Post Entry Performance of Firms, 13(4), December, pp. 421-440.

Glaeser, E., H. Kallal, J. Scheinkman and A. Shleifer (1992), "Growth of Cities", Journal of Political Economy 100, pp. 1126-1152.

Griliches, Z. (1979), "Issues in Assessing the Contribution of R\&D to Productivity Growth", Bell Journal of Economics 10, pp. 92-116.

Griliches, Z. (1992), “The Search for R\&D Spillovers”, Scandinavian Journal of Economics 94, pp. 29-47.

Jaffe, A., M. Trajtenberg and R. Henderson (1993), "Geographic Localisation of Knowledge Spillovers as Evidenced by Patent Citations", Quarterly Journal of Economics 63, pp. 577-598.

Jensen, M.C. (1993), "The Modern Industrial Revolution, Exit, and the Failure of Internal Control Systems", Journal of Finance 48, pp. 831-880.

Kaldor, N. (1934), “The Equilibrium of the Firm”, Economic Journal 44, March, pp. 60-76.

Kortum, S. and J. Lerner (1997), "Stronger Protection or Technological Revolution: What is Behind the Recent Surge in Patenting?", Working Paper No. 6204, National Bureau of Economic Research (NBER), Cambridge, MA.

Krugman, P. (1991), Geography and Trade, MIT Press, Cambridge.

Loveman, G. and W. Sengenberger (1991), "The Re-emergence of Small-scale Production: An International Comparison", Small Business Economics 3, pp. 1-37.

Lucas, R.E. (1978), "On the Size Distribution of Business Firms", Bell Journal of Economics 9, pp. 508-523.

Nelson, Richard R. and Sidney G. Winter (1982), An Evolutionary Theory of Economic Change, Harvard University Press, Cambridge.

Porter, Michael E. (2000), "Clusters and Government Policy", Wirtschaftspolitische Blaetter, 47(2), pp. 144-154.

Prevenzer, M. (1997), “The Dynamics of Industrial Clustering in Biotechnology", Small Business Economics, 9(3), pp. 255-271.

Reynolds, Paul D. (1997), “Who Starts New Firms?”, Small Business Economics 9, pp. 449-462. 


\section{DSTI/DOC(2001)2}

Reynolds, Paul D., Brenda Miller and Wilbur R. Maki (1995), "Explaining Regional Variation in Business Births and Deaths: US 1976-1988”, Small Business Economics 7, pp. 389-407.

Reynolds, Paul D., David J. Storey and Paul Westhead (1994), "Cross National Comparison of the Variation on the New Firm Formation Rates", Regional Studies 27, pp. 443-456.

Romer, P.M. (1990), “Endogenous Technological Change”, Journal of Political Economy 98, pp. 71-101.

Romer, Paul M. (1986), "Increasing Return and Long-Run Growth", Journal of Political Economy 94, pp. 1002-1037.

Romer, Paul M. (1994), “The Origins of Endogenous Growth”, Journal of Economic Perspectives, 8(1), Winter, pp. 3-22.

Saxenian, A. (1990), "Regional Networks and the Resurgence of Silicon Valley", California Management Review 33, pp. 89-111.

Scherer, F.M. and D. Ross (1990), Industrial Market Structure and Economic Performance, Houghton Mifflin Company, Boston, MA.

Scherer, F.M. (1991), "Changing Perspectives on the Firm Size Problem", in Z. Acs and D.B. Audretsch (eds.), Innovation and Technological Change: An International Comparison, University of Michigan Press, Ann Arbor, pp. 24-38.

Scherer, F.M. (1992), "Schumpeter and Plausible Capitalism", Journal of Economic Literature, 30(3), pp. 1416-1433.

Thurik, A.R. (1999), "Entrepreneurship, Industrial Transformation and Growth", in G.D. Libecap (ed.), The Sources of Entrepreneurial Activity. Vol. 11, Advances in the Study of Entrepreneurship, Innovation, and Economic Growth, JAI Press, Stamford, CT, pp. 29-65.

Viner, Jacob (1932), "Cost Curves and Supply Curves", Zeitschrift fur Nationaloekonomie 3, pp. 23-46.

Wennekers, S. and A.R. Thurik (1999), "Linking Entrepreneurship and Economic Growth", Small Business Economics 13, pp. 27-55.

Wessner, Charles (ed.) (2000), The Small Business Innovation Research Program (SBIR), National Academy Press., Washington, DC.

Winter, Sidney G. (1984), "Schumpeterian Competition in Alternative Technological Regimes", Journal of Economic Behaviour and Organization 5, September-December, pp. 287-320. 